\title{
AINDA SOBRE O COMODATO: TERMINOLOGIA E GERAÇÕES EXEGÉTICAS DE ESCRITORES SOBRE A RESPONSABILIDADE DO COMODATÁRIO
}

\author{
STILL ON THE LOAN FOR USE: TERMINOLOGY AND INTERPRETATION GENERATIONS OF \\ WRITERS ON LIABILITY OF THE BORROWER
}

\section{Rodrigo de Lima Vaz Sampaio*}

\begin{abstract}
Resumo:
O comodato deve ser analisado tendo-se em vista duas expressões das fontes romanas: "beneficium tribuere" e "custodiam praestare" A primeira decorre da nomenclatura da fattispecie, que, no Direito Romano, alternava-se entre "utendum dare" e "commodare". A segunda diz respeito à responsabilidade do comodatário. Devido à complexidade desta, um panorâma da literatura jurídica leva à construção de "três gerações exegéticas de escritores sobre a responsabilidade do comodatário" Chega-se, também, à conclusão de que os critérios desta podem e devem dialogar em uma mesma relação jurídica.
\end{abstract}

Palavra-chaves: Utendum dare. Commodare. Beneficium tribuere. Gerações exegéticas. Custodiam praestare. Responsabilidade objetiva e subjetiva.

\begin{abstract}
:
The loan for use must be examined considering two expressions of the roman sources: "beneficium tribuere" and "custodia praestare". The first branch off the name of the fattispecie, that, in Roman Law, switched between "utendum dare" and "commodare" The second refers to the liability of the borrower. Due to its complexity, an outlook of juridic literature leads to the construction of "three interpretation generations of writers on liability of the borrower" Also, arrives at the upshot that the criteria of liability can and must dialogue in the same legal relationship.
\end{abstract}

Keywords: Utendum dare. Commodare. Beneficium tribuere. Interpretation Generations. Custodiam praestare. Strict and Subjective Liability.

1. Introdução ${ }^{1}$

Este presente estudo visa tratar de dois assuntos conexos ao instituto do comodato, que são pouco difundidos, ao menos, no Brasil: sua nomenclatura e a evolução da responsabilidade do comodatário, ambos no Direito Romano.

Aluno do Curso de Pós-Graduação da Faculdade de Direito da Universidade de São Paulo. Diplomado no Corso di Alta formazione in Diritto Romano - 2010-2011, pela Università degli Studi di Roma I " $L a$ Sapienza". Este estudo teve a orientação do Professor Eduardo Cesar Silveira Vita Marchi, titular da Cadeira de Direito Romano.

Advertência quanto à metodologia empregada no artigo: todas as traduções são "livres" (pessoais). Utilizou- 
O comodato, "gratuitous loan of a thing" [= "empréstimo gratuito de uma coisa"], pertence aos denominados "contratos reais" isto é, cuja a entrega da coisa o "beneficium tribuere" de Paul. 29 ad ed., D. 13, 6, 17, 3 é indispensável para sua existência. ${ }^{2}$

Neste caminho, após esta breve introdução (item 1), a terminologia do instituto será esmiuçada, com especial destaque para a (co-)existência de duas expressões no Direito Romano - "utendum dare" e "commodare" que relevam justamente o comportamento do comodante, ou melhor, o ato de entrega (item 2 ). ${ }^{3}$

Por outro lado, se o "beneficium tribuere" revela um comportamento gratuito do comodante, o estudo da responsabilidade no instituto foca-se, em grande parte, no "custodiam praestare" [= ao pé da letra, "responder por custódia"] do comodatário.

Mas uma análise desta última deve tentar evitar uma contaminação pelo eventual maniqueísmo científico que se poderia ter devido à presença de marco fortíssimo na responsabilidade do comodatário, que é a obra de Franco Pastori ${ }^{4}$ - como ocorreu com alguns estudiosos que escreveram após este. ${ }^{5}$

Assim, afastando-se de uma visão "pró" ou "contra" Franco Pastori, sem esconder o devido mérito de sua obra, propõe-se uma divisão da doutrina, segundo os diversos entendimentos encontrados - e não apenas tendo-se em vista a cronologia determinada por um marco/data -, em três "gerações exegéticas de escritores sobre a

se dos parênteses "( )" ou dos colchetes "[]" para se referir a palavras ou expressões que não se encontram no original. Esses últimos foram ainda utilizados quando necessária a tradução de uma expressão ou de um texto específico no decorrer do trabalho.

Salvo os textos dos Digesta e das Iustiniani Institutiones, que foram todos obtidos na edição de KRUEGER, Paul, e MOMMSEN, Theodor. Corpus Iuris Civilis Novellae Institutiones Digesta, v.1; e das Gai Institutiones, extraídos de KRUEGER, Paul, e STUDEMUND, Wilhelm. Gai Institutiones. Collectio Librorum Ivris Anteivstiniani, v. 1; as obras ou coletâneas das fontes antigas, onde essas foram colhidas, são mencionadas, quando for necessário, in loco.

2 BERGER, Adolf. Encyclopedic Dictionary of Roman Law (1953). Philadelphia: American Philosophical, 1980. p. 399. Cf. item 2, infra, sobre Paul. 29 ad ed., D. 13, 6, 17, 3.

3 A importância do estudo desta terminologia encontra-se, por exemplo, em uma série de fontes posteriores que ajudaram a moldar o direito brasileiro e lusitano: L. Vis. 5, 5, 2, traz a extensão e o conteúdo do beneficium; Siete Partidas 5, 2 pr.-1, definem as espécies do empréstimo; Ord. Filip. 4, 53 pr.-1, após um estranho silêncio nas Ordenações Portuguesas anteriores, retomam o conceito; art. 478 da Consolidação de Teixeira de Freitas, art. 1.248 do CC (Código Civil)/16 revog. [= art. 579 do CC/02], arts. 1.506-1.508 do CC Português de 1867 revog., e art. 1.129 do CC Português, enunciam o instituto. Cf., também, sobre a terminologia em outras línguas, ZIMMERMANN, Reinhard. The Law of Obligations - Roman Foundations of the Civilian Tradition (1990). London: Oxford, 1996, p. 188-190.

4 PASTORI, Franco. Il commodato in diritto romano (1954). 3 ed. Milano: Cisalpino, 1995, p. XV-476.

5 Uma monografia atual sobre o tema de TARDIVO, Carlo-Maria. Studi sul " commodatum ». Archivio Giuridico "Filippo Serafini", v. 204, p. 44-451983; refere-se à obra de Franco Pastori não somente como definitiva, mas até mesmo que existia um mundo "pré-" e "pós-" este autor. Cf. a influência de Franco Pastori na terceira geração exegética de escritores sobre responsabilidade do comodatário, que determina um engessamento em toda uma parte da posterior doutrina, no item 3. 3., infra. 
responsabilidade do comodatário". "Esta divisão tem como objetivo maior delinear a evolução da responsabilidade do comodatário por parte da doutrina, e, assim, descortinar seu "estado de arte" atual.

Embora a tese dominante, que seria a da segunda geração exegética, seja, sem sombra de dúvidas, a de que o comodatário respondia pela custodia no período clássico, e por culpa ou diligentia na época justinianéia, ${ }^{7}$ existem posicionamentos absolutamente divergentes antes e após a sua criação.

A primeira geração de escritores sempre foi polarizada entre os posicionamentos de Joham Christian Hasse, ${ }^{8}$ segundo o qual a responsabilidade do comodatário sempre teria sido subjetiva desde o princípio, e de Julius Baron ${ }^{9}$, que sustenta exatamente o contrário, ou seja, que a responsabilidade do comodatário teria sido, até mesmo com Justinianeu, baseada na custodia.

E, por fim, criou-se, após a tese tradicional de Franco Pastori, uma terceira geração exegética de escritores sobre a responsabilidade do comodatário, que ora "copiam" a segunda geração, ${ }^{10}$ ora retomam os entendimentos da primeira. ${ }^{11}$

Sem delongas, passemos a análise dos dois lados da moeda: "beneficium tribuere" e "custodiam praestare"

6 Uma tarefa semelhante a esta já tentou ser desenvolvida, de forma mais tímida, por ARANGIO-RUIZ, Vincenzo. Responsabilità contrattuale in diritto romano (1927). 2. ed. Napoli: Jovene, 1987. p. 62-99, e, de forma mais abrangente e sistemática, pelo próprio PASTORI, Franco. Il commodato ... cit., p. 213-229. Esta proposta didática de divisão em três gerações exegéticas sobre a responsabilidade do comodatário não deseja reunir todos os autores que incidenta ou casualmente escreveram sobre o tema, mas apenas os principais doutrinadores (com destaque para aqueles que escreveram especificadamente sobre a responsabilidade do comodatário).

7 Esta tese começou a se desenvolver, embora sempre com as nuanças de cada autor e com raras exceções, em 1927, por ARANGIO-RUIZ, Vincenzo. Responsabilità... cit., p. 62-99; e, em 1938, por LUZZATTO, Giuseppe Ignazio. Caso fortuito e forza maggiore come limite alla responsabilità contrattuale. La responsabilità per custodia. Milano: Giuffrè, 1938. v. 1, p. 145-146, segundo o qual o comodatário respondia originalmente por custodia, passando no direito pós-clássico a responder por culpa, e no período justinianeu por exactissima diligentia. Mas a consolidação deste posicionamento somente ocorreria, em 1954, quanto ao presente instituto, com a obra de Franco Pastori.

8 HASSE, Joham Christian. Die «Culpa » des römischen Rechts. 2. ed. Bonn: Adolph Marcus, 1838. p. 211218.

9 BARON, Julius. Pandekten. 9 ed. Leipzig: Duncker \& Humblot, 1896. p. 427, 429-430, 505-506 (= §§ 237 e 275). Cf., principalmente, BARON, Julius. Die Haftung bis zur höheren Gewalt. In: Archiv für die Civilistische Praxis 1892, v. 78, p. 202-310; e BARON, Julius. Diligentia exactissima, diligentissimus paterfamilias oder die Haftung für Custodía. Archiv für die Civilistische Praxis, v. 52, p. 44-95, 1869.

10 Entre os quais, o artigo científico mais recente sobre o tema de MERCADO, Javier Belda. La responsabilidad del comodatario en el derecho romano. Revista Electrónica de la Facultad de Derecho de la Universidad de Granada, Granada, 2007, p. 1-23.

1 Cf., entre outros, TARDIVO, Carlo-Maria. op. cit., p. 82-91; SCHERILLO, Gaetano. Comodato (diritto romano). In: Enciclopedia del Diritto, v. 7, 1960. p. 981-992. Existe também outros posicionamentos relevantes, como o de POLÁCEK, Vojtech. Comodato e furto: spunti d'interpretazione dialettica. Labeo: Rassegna di Diritto Romano, v. 19, p. 161-184, 1973; e o de SERTORIO, Luigi. La "culpa in concreto" nel diritto romano e nel diritto odierno. Torino: Fratelli Bocca, 1914. p. 41-43. 
2. A terminologia do comodato no Direito Romano:"commodare" e "utendum dare"

Não é possível tratar das duas expressões utilizadas pelas fontes romanas "utendum dare" e "commodare" sem fazer, ao menos, um rápido aceno para a origem extrajurídica do instituto. ${ }^{12}$

Franco Pastori ${ }^{13}$ acredita que, pelo reconhecimento jurídico, pode-se perceber o processo evolutivo do comodato, ou seja, de como um mero vínculo social teria se transformado em um negócio jurídico.

Em Paul. 29 ad ed., D. 13, 6, 17, 3, ${ }^{14}$ o jurista teima em explicar, comentando o relativo edito, o porque que o empréstimo de uso gratuito, isto é, uma oferta espontânea, possivelmente grande, que remete ao espírito solidário de quem dela dispõe

12 Como também é igualmente impossível tratar da evolução da responsabilidade do comodatário sem saber quando o comodato é considerado um contrato e o comodatário passa a poder ser juridicamente demandado.

13 PASTORI, Franco. Il commodato ... cit., p. 1-2. No plano histórico, abre-se a oportunidade de controlar a intervenção do direito na sanção de uma relação, que seria, a princípio, de autonomia priwada, ou seja, ainda não considerada como integrante do ordenamento jurídico. Mas, além disso, a evolução histórica do comodato pode iluminar o processo evolutivo do negócio jurídico enquanto categoria abstrata, não criada pelo direito, mas com profundas raízes sociais. Em suma, e em breves linhas, a história do comodato revela parte do desenvolvimento do sistema contratual romano.

14 "Sicut autem voluntatis et officii magis quam necessitatis est commodare, ita modum commodati finemque praescribere eius est qui beneficium tribuit. cum autem id fecit, id est postquam commodavit, tunc finem praescribere et retro agere atque intempestive usum commodatae rei auferre non officium tantum impedit, sed et suscepta obligatio inter dandum accipiendumque. geritur enim negotium invicem et ideo invicem propositae sunt actiones, ut appareat, quod principio beneficii ac nudae voluntatis fuerat, converti in mutuas praestationes actionesque civiles. ut accidit in eo, qui absentis negotia gerere inchoavit: neque enim impune peritura deseret: suscepisset enim fortassis alius, si is non coepisset: voluntatis est enim suscipere mandatum, necessitatis consummare. igitur si pugillares mihi commodasti, ut debitor mihi caveret, non recte facies importune repetendo: nam si negasses, vel emissem vel testes adhibuissem. idemque est, si ad fulciendam insulam tigna commodasti, deinde protraxisti, aut etiam sciens vitiosa commodaveris: adiuvari quippe nos, non decipi beneficio oportet. ex quibus causis etiam contrarium iudicium utile esse dicendum est." [ = "Assim como entregar (alguma coisa) em comodato é mais por vontade e favor do que por necessidade, a prescrição do modo e limite do comodato é analisada frente aquele que faz (a entrega do) o benefício. Mas, depois que o faz, não somente o mesmo favor o impede de prescrever o término e pedir, por uma ação, a devolução da coisa, privando intempestivamente (o comodatário) do uso da coisa entregue, mas também aceita a obrigação de dar e receber, uma vez que se fez reciprocamente o negócio, e, por isso, do mesmo modo foram estabelecidas as ações. Desta forma, o que, a princípio, foi um ato de vontade livre e de favor converte-se em prestações mútuas e ações civis, como também acontece com aquele que foi gestor de negócios de um ausente, pois (o ausente) não os deixaria perder impunemente - se o primeiro não o tivesse feito, talvez outrem teria se encarregado deles - e constitui ato voluntário aceitar um mandato e o cumprir. Portanto, se tu me deres em comodato as tábuas de escrever para que um devedor me desse caução, não a retomarás a reclamando antes do prazo, pois, se me as tivesse negado, as teria comprado ou utilizado de testemunhas. E o mesmo ocorre se me entregas madeiras para construir uma casa e depois as retoma, ou, mesmo sabendo que tinham algum defeito, entregou-as a mim, porque se deve ajudar com um benefício, $\mathrm{e}$ não enganar. Por essas razões se há de dizer que também caiba a ação contrária útil’]. 


\section{(o comodante), torna-se para este obrigatório, após a entrega do benefício. " "Entrega" que} ainda demonstra o caráter essencialmente real do instituto. ${ }^{16}$

is PASTORI, Franco. Il commodato ... cit., p. XVI. Trata-se do questionamento sobre o motivo pelo qual o comodato, de simples relação da praxis social realizada entre pessoas amigas passa a ter a qualificação de negócio jurídico, ou seja, não é nada mais que o problema proposto pela moderna ciência do direito que não entende o negócio jurídico como formal criação do ordenamento jurídico, da lei lato sensu, mas como resultado de uma recepção, por parte deste, de uma sistematização de interesses já obrigatórios por meio de normas sociais. Grande parte da exegese do texto de Paulo está depositada na expressão "beneficium tribuit" [= "entrega o benefício"], que assinalaria a natureza jurídica do comodato. Esta expressão aponta para o comportamento de quem dá, confere o benefício, ou seja, do comodante, assinalando também o caráter real do comodato.

O caráter real (genético) deste negócio jurídico, a partir de seu reconhecimento jurídico, seria cabalmente diagnosticado, no Direito Civil moderno, por FORCHIELLI, Paolo. I contratti reali. Milano: Giuffrè, 1952. p. 2-5, 9, 109-110. Segundo este, a figura do contrato real está intrinsecamente ligada à relevância da entrega durante a formação do negócio jurídico, sem a qual este não se reputará perfeito. Assim, a entrega faz parte da própria fattispecie contratual, contrahendi causa e não solvendi causa, como nos contratos consensuais. Mas, por outro lado, as legislações vigentes não conhecem um tipo genérico de contrato real, mas, pelo contrário, disciplinam figuras contratuais que a tradição sempre considerou reais e outras que somente atualmente teriam sido consideradas. De qualquer forma, em todas esses tipos contratuais menciona-se a entrega - o "beneficium tribuit" de Paulo.

16 Ainda sobra a entrega, FORCHIELLI, Paolo. op. cit., p. 109-110, 114-121, vai além, passando a questionar sua própria função. O problema que se impõe é descobrir o motivo pelo qual a lei não atribui, frente aos contratos reais, uma relevância jurídica a uma vontade, manifestada ou não pelo ato de entrega, prevalecendo o ato de entrega em si. Uma questão que sofre variações nas mais diversas relações contratuais, mas com a certeza de que não se pode mais considerar em vigor o princípio da imperatividade ou da inderrogabilidade dos contratos reais, simplesmente igualando o Direito Romano com o Direito Civil moderno, sem qualquer fundamentação. Falta, de fato, no ordenamento uma norma de caráter genérico que imporia a todas as figuras dos contratos reais a inderrogabilidade da entrega; e mesmo que este princípio existisse, ele não deve ser analisado genericamente, mas frente às figuras específicas de cada contrato real. Mesmo assim não se encontra uma só norma que se refira à realidade dos contratos, ou à imperatividade desta.

Entretanto, existe de fato um dilema interpretativo, que permitiria o uso de critérios sistemáticos e históricos na busca do fundamento e da função dos contratos reais. Pela interpretação sistemática, percebe-se que os contratos reais inserem-se no campo mais amplo dos contratos, âmbito este de natureza dispositiva, onde normas de caráter imperativo seriam excepcionais e a forma no campo contratual seria igualmente livre, no sentido que os sujeitos são livres para escolherem a forma expressamente prevista na lei ou qualquer outra que desejarem, salvo se a forma for prescrita pela lei sob pena de nulidade, conforme art. 1.325 do CC Italiano (arts. 104, III, 108 e 109 do CC/2002). E, nessas hipóteses em que a lei exige uma forma específica sob pena de nulidade, ela geralmente adota uma linguagem muito diferente da que define as figuras típicas dos contratos reais, cominando a nulidade ou uma outra sanção menor, se a forma for desobedecida.

Não solucionado pelo aspecto sistemático, resta somente o método histórico, para que se tente afirmar a existência do princípio da inderrogabilidade da entrega para a formação dos contratos reais. Infelizmente os trabalhos realizados no Código Civil Italiano, seja no vigente, seja no revogado, bem como no Código Civil Francês não tratam da questão. Só se pode deduzir que desta falta de tratamento, objetivou-se deixar a matéria como estava sendo tratada anteriormente, vale dizer, como era tratada no Direito Romano. Enfim, se existisse este princípio na legislação italiana atual, o seu único fundamento seria o Direito Romano. E parece que este princípio existia no período clássico do Direito Romano, com um significado muito próximo ao que a doutrina moderna the confere. No Direito Romano clássico, salvo a controvérsia sobre o exato sentido da fórmula "re contrahere", é certo que o empréstimo ou o depósito não produziam obrigações jurídicas quando materialmente não houvesse a entrega.

Essa última dependia do formalismo próprio do direito clássico, reconhecido, no ius civile e no ius honorarium, por determinadas causae obligationis, e não em uma norma genérica que atribuísse relevância da entrega nos nuda pacta. Também é certo que o sistema clássico contratual evoluiria a ponto de se alterar 
A origem do comodato remonta à história primitiva da humanidade, sendo que, provavelmente, antecede à própria troca, que já retroage, por sua vez, em muitos séculos à compra e venda. ${ }^{17}$

Francisco Cavalcanti Pontes de Miranda ${ }^{18}$ conta que existem referências ao empréstimo de uso até o século II. a. C., mas não à figura jurídica do comodato, permanecendo no meio das relações sociais da amizade e da benevolência, relações anteriores à criação da actio in factum.

Pierluigi Zanninni ${ }^{19}$ acredita ser muito controversa a hipótese do empréstimo de uso ter gozado ou não, antes da intervenção do pretor pela actio in factum, uma proteção indireta do ius civile, ou se haveria passado oito séculos sem proteção, até chegar a época de Quinto Múcio Sévola, estando, neste segundo caso, confinado nos institutos regulados por normas ético-sociais, mas não jurídicas. ${ }^{20}$

Não se tem certeza se a actio in duplum de natureza penal, prevista nas $L$. XII Tab. 3, 1, para um negócio semelhante ao depósito e ao comodato, pudesse se aplicar a estes, conforme PS. 2, 12, 11 [= Paul., Coll. 10, 7, 11]. ${ }^{21}$

Neste sentido, Pierluigi Zanninni ${ }^{22}$ acredita que, embora o comodato, antes de ingressar no sistema contratual romano, não pudesse ser tutelado indiretamente pela

radicalmente, reconhecendo tutela genérica à vontade privada independentemente da forma contratual, nominada ou inominada, que viesse expressa. Trata-se da afirmação do princípio da liberdade das formas contratuais, e as antigas causae obligationis viriam a perder seu caráter taxativo, passando a determinar apenas quais eram os tipos contratuais nominados. Chega-se então, na essência, ao regime ainda hoje vigente. Assim, a peculiaridade do sistema romano clássico, vale dizer, as causae obligationis, com base nas quais era possível estruturar um princípio da inderrogabilidade da entrega nos contratos reais, não existe mais hoje, e com ela também não se aplicaria este princípio. Assim, o método histórico não apenas não nos fornece argumentos suficientes para sustentar o princípio da inderrogabilidade da entrega hoje, mas também demonstra que este princípio não seria vigente.

Por fim, devido à impossibilidade atual de se encontrar um princípio da inderrogabilidade, no caso do comodato, o fundamento de seu caráter real somente pode se encontrar em sua gratuidade, ressalvada a força vinculante de um mero "pacto (consensual) de comodato", uma espécie de promessa de comodato. MARMITT, Arnaldo. Comodato (1991). 3 ed. Rio de Janeiro: AIDE, 2002, p. 11-12.

18 MIRANDA, Francisco Cavalcanti PONTES de. Tratado de Direito Privado: parte especial. Direito das Obrigações: contrato de seguro (continuação) - seguro de vida - seguro de acidentes pessoais - seguro de responsabilidade - seguro de crédito - seguro de riscos especiais e de universalidade - seguros mútuos resseguro - contrato de comodato - contrato de doação - contrato de hospedagem. 2. ed. Rio de Janeiro: Borsoi, 1964. t. 46, p. 131.

19 ZANNINNI, Pierluigi. Comodato nel diritto romano. Digesto delle Discipline Privatistiche, v. 3, p. 32-33, 1998.

20 O que poderia ter originado, conforme ZANNINNI, Pierluigi. op. cit., p. 32-33, certa perplexidade, uma vez que se trata de um instrumento negocial particularmente importante em uma economia essencialmente agrícola-pastoril, fundada, por sua própria natureza, na auto-suficiência dos meios de produção, longe, então, do bem-estar que só pode decorrer de uma atividade do tipo mercantil.

21 "Ex causa depositi lege duodecim tabularum in duplum actio datur, edicto praetoris in simplum. [= "Segundo a causa do depósito, pela lei das doze tábuas, dá-se lugar a uma actio in duplum, (mas) pelo edicto pretoriano (a uma actio) in simplum"]. Texto em latim de BAVIERA, Johannes, FIRA (Fontes Ivris Romani Anteiustiniani) II.

22 ZANNINNI, Pierluigi. op. cit., p. 33. 
fiducia cum amico, ${ }^{23}$ uma vez que não existem registros nas fontes, seria mais provável que o empréstimo de uso já poderia encontrar uma tutela indireta através da legis actio per condictionem, que a Lex Silia (200-197 a. C.) introduziu primeiro para os créditos certae pecuniae, e que, mais tarde, a Lex Calpurnia (149 a. C.) considera aplicável também para os créditos de omni certa re, ${ }^{24}$ como recordado por Gai. 4, $19 .{ }^{25}$ Mas, ${ }^{26}$ terminologicamente, foi a expresão "utendum dare" [= "dar para se servir; entregar o uso de algo"] a denominação primitiva do comodato, nome este que se

23 SOLAZZI, Siro. Recensão a PASTORI, Franco. Il commodato nel diritto romano: con contributi allo studio della responsabilità contrattuale. Milano: Giuffrè, 1954. IURA: Rivista Internazionale di Diritto Romano e Antico, v. 6, 1955, p. 258, considera também correto dizer que se recorria à fiducia em tempo mais antigo para conceder o uso gratuito da coisa, mas não se poderia afirmar que a fiducia aplicava-se, primeiramente, aos imóveis e, somente depois, aos móveis, já que Labeão, em Ulp. 28 ad ed., D. 13, 6, 1, 1, utiliza a palavra "commodare", e não "fiducia".

Segundo MICHEL, Jacques. Gratuité en droit romain. Bruxelles: Université Libre de Bruxelles - Institut de Sociologie, 1962. p. 95 (=n. 145), após Labeão instaurou-se neste texto uma conhecida controvérsia terminológica, limitando o emprego de "commodare" aos móveis, e, assim, "utendum dare" poderia se referir tanto aos móveis como aos imóveis. Este debate seria desprovido de efeitos práticos, já que antes de Ulpiano, no edito de Pacônio, empregava-se "utendum dare"

${ }^{24}$ ZANNINNI, Pierluigi. op. cit., p. 32-33, ainda recorda, em primeiro lugar, que o comodato vem previsto ao lado do mútuo e do penhor na rubrica edital "De rebus creditis" (D. 12,1) ao invés de estar, com o depósito no título "De bonae fidei iudiciis", e, em segundo lugar, da forte analogia entre a estrutura da condictio e da actio commodati in factum. É possível que Ulpiano visse no credere uma categoria contratual muito restrita, a ponto de incluir o comodato e o penhor ao lado do mútuo na mesma rubrica. Por outro lado, com quase certeza, na metade do século II. a. C., o direito já reconhecia o cabimento da actio furti, por parte do comodante, quando o comodatário usasse da coisa para um fim diverso do acordado ou contrariamente a natureza da coisa. Disto decorre que a actio furti a condictio ex causa furtiva sancionavam o comportamento doloso do comodatário que após usar da coisa, recusa-se a entregá-la. Assim, é fato que o empréstimo de uso gratuito, longe de estar misturado com as relações estranhas à esfera do direito, encontre já, antes da tutela pretoriana, uma proteção extremamente rigorosa e eficaz, mesmo se indireta, por parte do ordenamento jurídico.

25 "Haec autem legis actio constituta est per legem Siliam et Calpurniam, lege quidem Silia certae pecuniae, lege uero Calpurnia de omni certa re" [= "Essa ação da lei foi instituída pelas Leis Sília e Calpúrnia, a primeira para as ações de quantia certa e a segunda para as ações de coisa certa"].

26 MICHEL, Jacques. op. cit., p. 61-66, 95-102 (=n. 80-89, 139-152), aponta que, no tratado "De Agri Cultura" [= "Acerca da Agricultura"] (160 a. C.) de Marcius Porcius Cato (234 a.C. - 149 a.C.), conhecido como Catão, o "Antigo", conservaram-se dois textos relativos ao comodato na vida campestre. A obra recolhe um conjunto de textos que conta a vida rural da república romana e como administrar uma granja. Em ambos os fragmentos ele se dirige não ao proprietário, mas ao agente do poder real da província, e instiga a prática do comodato pelos vizinhos (os textos em latim citados nesta nota de rodapé foram obtidos na coleção Loeb Classical Library Edition, Harvard University, 1934).

Cato, De Agric. 4: "[...] Vicinis bonus esto; familiam ne siveris peccare. Si te libenter vicinitas videbit, facilius tua vendes, opera facilius locabis, operarios facilius conduces; si aedificabis, operis, iumentis, materie adiuvabunt: siquid bona salute usus venerit, benigne defendent." [= "Seja um bom vizinho e não permita que seus subalternos cometam ofensas. Se você for popular na vizinhança será fácil para você vender a produção, para fazer sair o seu serviço e para apreender mão de obra extra. Se você construir, os vizinhos te ajudarão com o seu serviço, seus subalternos e seus instrumentos. Se tiver um problema com você, que Deus o impeça, eles estarão felizes por estarem ao seu lado"].

A ajuda que o fazendeiro tem juridicamente é manifesta, dentro do campo da gratuidade, de três formas. A primeira é por um adicional de mão de obra, mas Catão não enuncia se o trabalho será realizado pelos próprios vizinhos, ou por seus escravos, e, neste último caso, ocorreria o comodato. A segunda é pelo uso de 
repetia nos editos anuais do pretor republicano, segundo se percebe do espúrio Ulp. 28 ad ed., D. $13,6,1,1 .^{27}$

animais de tiro e carga, que configura novamente um comodato; e a terceira pelo fornecimento de madeira para a construção, e, mesmo neste caso, pode-se ter um comodato, se o material for restituído após o uso, como o exemplo de Paul. 29 ad ed., D. 13, 6, 17, 3.

Cato, De Agric. 5, 3. "[...] Duas aut tres familias habeat, unde utenda roget et quibus det, praeterea nemini." [= "Ele deve ter dois ou três lares e não mais, para quem ele empreste e para quem ele dê"].

Este segundo texto é mais importante ainda, pois ele se refere com mais ênfase ao comodato. Primeiramente, ele confirma uma terminologia muito corrente na época e mostra o mecanismo do comodato praticado entre vizinhos de forma sistemática. Além disso, demonstra que o comodato é um serviço que se opera a título de reciprocidade, entre partes que estão em pé de igualdade.

Os preceitos de Catão se tornam particularmente interessantes quando comparados com a atitude de Marcus Terentius Varro (116 a.C. P - 27 d.C.), ou Varrão, em "Res Rusticae", [= "Assuntos do Campo"] (37 d.C.) quase um século e meio mais tarde.

Var., Res Rust. 1, 15: "Praeterea sine saeptis fines praedi satione arborum tutiores funt, ne familiae rixent cum vicinis ac limites ex litibus indicem quaerant. Serunt alii circum pinos, ut habet uxor in Sabinis, alii cupressos, ut ego habui in Vesuvio, alii ulmos, ut multi habent in Crustumino; ubi id pote, ut ibi, quod est campus, nulla potior serenda, quod maxime fructuosa, quod et sustinet saepe ac cogit aliquot corbulas uvarum et frondem iucundissimam ministrat ovibus ac bubus ac virgas praebet saepibus et foco ac furno. Scrofa, Igitur primum haec, quae dixi, quattuor videnda agricolae, de fundi forma, de terrae natura, de modo agri, de finibus tuendis." [= "Além disso, se não houver cercados, as fronteiras do estado são feitas mais seguras plantando-se árvores, as quais previnem os servos de brigar com os vizinhos, e torna desnecessário fixarem fronteiras com processos. Alguns plantam pinheiros ao redor das beiras - como minha mulher fez em suas fazendas Sabinas; outros plantam ciprestes - eu o fiz no meu terreno no Vesúvio; e ainda outros plantam olmos - como muitos fizeram próximo de Crustumeria. Onde isso for possível, pois se trata de uma planta, não há melhor árvore para se plantar. É extremamente lucrativo, quando isso com frequência aguenta e reúne muitas cestas de uva, campos mais agradáveis, folhagens para as ovelhas e para o gado, linhas de mobília para a esgrima, e madeira para a lareira e a fornalha. 'Por isso estes pontos que eu discuti', continua Scrofa, "são os quatro que devem ser observados pelo fazendeiro: a topografia da terra, a natureza do solo, o tamanho do lote, e a proteção das fronteiras"'].

Catão coloca em destaque uma fazenda familiar, de médio porte, que tem um proprietário independente. Nesta fazenda, não se dispõe de todos os instrumentos desejáveis para realizar a exploração, e o proprietário percebe que os seus vizinhos se encontram em igual situação. A necessidade os tornará solidários.

Varão se dedica a uma grande propriedade, que se comparada com a analisada por Catão, apresenta técnicas aplicadas em escala industrial. O proprietário aqui está em condições de possuir tudo o que for necessário e, com sorte, de gerar explorações contínuas de sua terra. $O$ autor vê os vizinhos mais como uma ameaça, do que como um socorro, sendo necessário que o proprietário se proteja de suas invasões e furtos.

O contraste entre a doutrina de Catão e de Varão é instrutiva pois demonstra como o progresso da produção e do comércio reduzem a importância dos serviços benévolos e, por conseqüência, dos contratos gratuitos, como o comodato.

27 "Huius edicti interpretatio non est difficilis. unum solummodo notandum, quod qui edictum concepit commodati fecit mentionem, cum Paconius utendi fecit mentionem. inter commodatum autern ef utendum datum Labeo quidem ait tantum interesse, quantum inter genus et speciem: commodari enim rem mobilem, non etiam soli, utendam dari etiam soli. sed ut apparet, proprie commodata res dicitur et quae soli est, idque et Cassius existimat. Vivianus amplius etiam habitationem commodari posse ait." [= "Não é dificil a interpretaf̧ão deste edito. Somente se deve perceber que aquele que concebeu o edito fez menção ao comodato, tanto quanto Pacônio fez menção ao uso. Mas, diz Labeão que, na verdade, entre o que se dá em comodato e o que se dá em uso há uma diferença, como entre o gênero e a espécie, já que se dá em comodato apenas a coisa móvel, mas não a coisa imóvel, enquanto se dá em uso também este. Porém, como parece, com certeza se diz que a coisa entregue em comodato, também pode ser a imóvel, e, assim também compreende Cássio. Viviano vai além: também pode ser entregue em comodato a habitação"].

Cf. ARANGIO-RUIZ, Vincenzo. Istituzioni di diritto romano. 14. ed. Napoli: Jovene, 2006. p. 313. No 
A palavra "commodatum" [= "comodato"] foi adotada pela primeira vez, de forma não oficial, pelas palavras de Juliano, embora, antes mesmos dessas, era utilizado para indicar uma das formas de relações entre as inúmeras que a expressão "utendum dare" abarca: aquela que tinha por objeto uma coisa móvel. ${ }^{28}$

Desta forma, nas fontes jurídicas e literárias alterna-se o emprego de "utendum dare" com o de "commodatum" embora esta última tenha prevalecido para se referir especificadamente a um negócio jurídico. ${ }^{29}$

Entretanto, a supremacia do substantivo "commodatum" somente teria sido possível após uma ampla evolução histórica e filológica.

Como em qualquer outra hipótese em que se envolva uma terminologia jurídica, no comodato, longe desse nome ser introduzido pela ciência do direito, ele teve sua origem na linguagem extrajurídica (leiga), em uma esfera de relações que se desenvolvem apenas no plano social, sem qualquer intervenção do direito. ${ }^{30}$

Assim, convém relembrar o que as expressões "utendum dare" e "commodare" representam na linguagem leiga, independentemente do sentido que elas assumiriam dentro da esfera técnica do direito. ${ }^{31}$

mesmo sentido, ALVES, José Carlos Moreira. Direito Romano - Instituições de Direito Romano - Parte especial - Direito das Obrigações - Direito de Familia - Direito das Sucessões (1965). 6. ed. Rio de Janeiro: Forense, 2005. v. 2, p. 127-128 (=n. 231).

WEISS, Egon. Institutionen des römischen Privatrechts. 2. ed. Basel: Recht und Gesellschaft, 1949. p. 348340 (= § 96), acredita que o uso nas fontes da expressão "utendum dare" decorra justamente da ideia que se deseja transmitir, isto é, "entrega gratuita do uso de uma coisa", e, em seguida, usa a expressão alemã "bittweise Überlassung" [= "entrega realizada"]. Também BARON, Julius. Pandekten ... cit., p. 505 (= $\S 275$ ), com o habitual rigor conceitual, utiliza a expressão "Leihe im engeren Sinn" [= "empréstimo em sentido estrito"], uma vez que, cf. RAMOS, Fernando Silveira. Dicionário Jurídico Alemão-Português. Coimbra: Almedina, 1995. p. 265, o substantivo "Leihe", embora habitualmente utilizado no sentido de "comodato", pode significar genericamente "empréstimo", o que também ocorreria com o verbo "leihen", podendo surgir alguma dúvida quanto à espécie de empréstimo - mútuo ou comodato - a que se referiria. Cf., igualmente, ZIMMERMANN, Reinhard. op. cit., p. 189, o qual afirma que "Leihe" designa o commodatum, enquanto "Darlehen" o mutuum.

GIRARD, Paul Frédéric. Manual élémentaire de droit romain. 4. ed. Paris: Arthur Rousseau, 1906. p. 527528, acrescenta que o "prêt à usage" [= "comodato"], graças à denominação "utendum datum", estaria no domínio dos direitos pessoais, e, pelo jus utendi, no âmbito dos contratos reais.

ARANGIO-RUIZ, Vincenzo. Istituzioni ... cit., p. 313-314 e ALVES, José Carlos Moreira. op. cit., p. 127128 (= n. 231). Assim, a expressão "utendum dare", embora mais antiga, denominava um gênero, dentro do qual encontravam-se diversas relações que conferiam um benefício a alguém, sendo que uma delas - sua espécie - foi se destacando do gênero e assumindo a roupagem do "commodatum"

PASTORI, Franco. Il commodato ... cit., p. 47.

30 PASTORI, Franco. Il commodato ... cit., p. 47. A existência extrajurídica da palavra é, de certa forma, óbvia, pois como se sabe o próprio negócio jurídico não é criado pelo direito, mas deriva da autonomia privada dos cidadãos que tem desejo de auto-regular seus interesses, considerando esses regulamentos como imperativos, já que são espontaneamente adotados. E, como qualquer situação fática, a esses, ainda no plano social, antes da intervenção jurídica, foram conferidos um nome, uma terminologia.

31 PASTORI, Franco. Il commodato ... cit., p. 47-48. 
Franco Pastori ${ }^{32}$ aponta alguns testemunhos colhidos nas fontes literárias que reproduzem a linguagem extrajurídica no seu sentido genuíno, trazendo referências às relações da prática social, das quais o comodato teria se originado.

No sentido literal, "commodare" significaria arranjar um "commodum" ou uma "commoditas", isto é, a utilidade que espontaneamente uma pessoa confere a outrem, tendo, por pano de fundo, recíprocas relações de amizade e de benevolência, como se pode perceber em um texto de Marcus Tullius Cicerus [Cícero], "Laelius de amicitia" [= (Lélio:) Acerca da Amizade] (44 a.C.):

Cic., De amic. 7: "Quomque plurimas

et maximas commoditates amicitia contineat

$$
[\ldots]^{\prime \prime}
$$

Em um outro texto de Cícero "In verrem" [= "Verrinas"] (70 a.C. $)^{33}$ a
"Visto que a amizade contém muitas e grandes vantagens $[\ldots] "$ entrega espontânea que fundamenta a expressão "commodare" é reconhecida na linguagem extrajurídica:

Cic., In verr. 4: "Advocatus commodat praesentiam suam amico."

Mais uma vez Cícero nos oferece um sentido mais determinado e próprio, indicando a retribuição de um serviço ou a entrega de qualquer coisa.

Cic., In verr. 6, 9: "Tritici modium $L X$ milia publice commodati".
"O advogado entrega [a título de comodato] seu presente ao amigo." .

\section{a}


"Utendum dare" ao contrário, na acepção literal não evoca o aspecto da gratuidade, mas põe em evidência o perfil do uti, do objeto da relação. Tanto que, mesmo em matéria jurídica, o espírito social dessa expressão manter-se-á, pois continuará a designar uma série de relações que comportam um $u t i$, independentemente da gratuidade, ou seja, não se trata de uma expressão privativa do comodato, mas se refere a uma série de relações jurídicas. ${ }^{35}$

A terminologia que ocorre nas fontes literárias mais antigas é empírica, já que advém de um tempo em que o comodato não era ainda representado por um negócio jurídico, o que seria uma meta da intervenção do direito. Mas, em um primeiro momento, o comodato encontra-se confundido com outras relações meramente sociais com as quais havia em comum ou a gratuidade ou o $u t i .^{36}$

Paul. 5 ad Plaut., D. 12, 5, 9 pr., ${ }^{37}$ chama atenção para a consideração jurídica do empréstimo de uso gratuito e depõe como a iurisprudentia adotou a terminologia da linguagem leiga e buscou a harmonizar com a finalidade jurídica do negócio. ${ }^{38}$

Esta percepção demonstra que a tutela jurídica do comodato não é muito remota, pois as descrições republicanas não consideram ainda o empréstimo de uso gratuito como um negócio jurídico no sistema contratual romano. Existem incertezas que afloram de Ulp. 28 ad ed., D. 13, 6, 5, 3, ${ }^{39}$ e dúvidas sobre a terminologia ainda presentes

35 PASTORI, Franco. Il commodato ... cit., p. 49-50. Assim, poder-se-ia cogitar que tanto "commodare" como "utendum dare" são expressões genéricas não idôneas para designar, isoladamente, um instituto como o empréstimo de uso gratuito, pois este necessita tanto da gratuidade, elemento implícito no "commodare", como do uti, próprio do "utendum dare" Uma designação precisa do empréstimo de uso gratuito teria requerido um emprego conjunto das expressões, se a linguagem extrajurídica e literária de "commodare" $\mathrm{e}$ "utendum dare" passassem intocadas para o mundo do direito.

36 Cf. PASTORI, Franco. Il commodato ... cit., p. 50. Como resulta da inscriptio do fragmento, Paul. 5 ad Plaut., D. 12, 5, 9 pr., ao comentar uma obra de Titus Maccius Plautus [Plauto], refere-se a um caso prático, como uma hipótese, de empréstimo de roupas. Plauto já tinha usado a expressão "utendum dare" em uma comédia sua denominada "Aulularia" [= "A Comédia do Pote de Ouro"] (escrita entre 194-191 a.C.), onde o uti designa as circunstâncias de fato e põe em relevo a finalidade e o seu âmbito, tomando em consideração o caráter da pessoa para o qual o uso era concedido:

Plaut., Aul. 1, 2, 17-19: "Cultrum, securim, pistillum, mortarium, quae utenda vasa semper vicini rogant, fures venisse atque abstulisse dicito." [ = "Uma faca, um machado, um pilão e um almofariz, equipamentos que sempre os vizinhos querem emprestar, inibe os ladrões e, por outro lado, defende todo o terreno"]. Obs.: o texto em latim foi obtido na coleção da Longman Publishing Group, Pearson Prentice Hall, 1988.

37 "Si vestimenta utenda tibi commodavero, deinde pretium, ut reciperem, dedissem, condictione me recte acturum responsum est: quamvis enim propter rem datum sit et causa secuta sit, tamen turpiter datum est." [= "Se eu te tivesse confiado vestidos para os usar, e, em seguida, eu te tivesse dado dinheiro para os comprar, diz-se que, adequadamente, devo propor a condictio, porque mesmo que se tenha dado uma coisa por determinada razão, ao se verificar a causa, deu-se sem dúvidas torpemente"]. Cf. PASTORI, Franco. Il commodato ... cit., p. 50.

39 "Commodatum autem plerumque solam utilitatem continet eius cui commodatur, et ideo verior est Quinti Mucii sententia existimantis et culpam prestandam et diligentiam et, si forte res aestimata data sit, omne periculum praestandum ab eo, qui aestimationem se praestaturum recepit." [= "Em regra, é comum que no comodato exista utilidade (apenas) para o comodatário, e, por isso, é mais exata a opinião de Quinto Múcio, pela qual este (o comodatário) responde tanto por culpa, como por diligência. Além disso, se por 
em Labeão, e só resolvidas definitivamente com Cassio e Viviano, em Ulp. 28 ad ed., D. $13,6,1,1$.

Assim, é muito provável que, no século I a. C., o comodato apenas gozava de uma tutela ex decreto, conferida caso a caso pelo pretor, não podendo ainda ser considerado como contrato, no sentido jurídico, mas apenas, como recordam as fontes literárias, um negócio socialmente imperativo.

Franco Pastori ${ }^{40}$ demonstra que a terminologia "commodare ... utendum" de Paul. 5 ad Plaut., D. 12, 5, 9 pr., é inadequada na época dos Severos, quando o comodato há muito já havia conquistado sua forma negocial e a palavra "commodare" assumiu um preciso sentido técnico. Essa expressão somente poderia ser compreendida se "commodare" significasse "entregar gratuitamente" requerendo o objetivo da entrega, enquanto "utendum dare" não trazendo necessariamente o elemento da gratuidade, necessitasse do "commodare"

A utilização ora de "commodare" no sentido de "conceder um benefício gratuitamente", e "utendum dare", no sentido de "dar algo em uso", deixaria incerta a terminologia que designa o empréstimo de uso gratuito dentro da prática social, somente acentuando ou o elemento da gratuidade, ou o uti.

Logo, juridicamente só poderiam existir duas construções sobre o tema: uma mais antiga, que necessita da presença do "utendum" ao lado do "commodare", e outra, mais recente, que já não precisa do primeiro. Isso demonstraria a aproximação que foi sendo feita dos termos, até se tornar desnecessário a presença do "utendum" 41

Além disso, Franco Pastori ${ }^{42}$ acredita que, na linguagem comum, a designação preferida foi "utendum dare" que relevava o uti, objetivo/objeto da relação, sendo a gratuidade decorrente das circunstâncias em que a relação era feita.

Seria Ulp. 28 ad ed., D. 13, 6, 1, 1, a prova que a primitiva terminologia jurídica também foi "utendum dare", o que, logo, explicaria, a contrario sensu, qual seria a terminologia mais corrente na linguagem leiga. ${ }^{43}$

acaso a coisa emprestada for estimada, aquele que aceitou suportar a avaliação responde (também) por todo o risco"].

40 PASTORI, Franco. Il commodato ... cit., p. 51.

4! Cf. PASTORI, Franco. Il commodato ... cit., p. 50. Afinal, trata-se de uma relação de gênero e espécie.

42 PASTORI, Franco. Il commodato ... cit., p. 52.

43 PASTORI, Franco. Il commodato ... cit., p. 53-54. Definitivamente, na linguagem extrajurídica a expressão predominantemente preferida é "utendum dare", por sua concepção que deriva das antigas relações de escambo, enquanto "commodare" é usado quando se deseja apontar a entrega gratuita que se baseia em relações de amizade e benevolência. Ulp. 28 ad ed., D. 13, 6, 1, 1, relembra Pacônio, o primeiro pretor que teria provavelmente concedido, via actio decretalis, tutela jurídica a um caso prático do uso gratuito, o qual "utendi fecit mentionem"

Pacônio não teria pensado no comodato como uma típica figura contratual, mas apenas teria se encontrado diante de um caso prático de empréstimo de uso gratuito, e a terminologia por ele usada somente poderia ser a derivada da linguagem leiga. Aliás, devia ser a mesma linguagem e terminologia utilizadas pelas partes no 
Entretanto, Siro Solazzi, ${ }^{44}$ querendo provar o relapso de Franco Pastori, duvida da afirmação de Ulp. 28 ad ed., D. 13, 6, 1, 1, que "Paconius utendi fecit mentionem" Pacônio teria escrito "utendum" sem "dare", mas segundo Gai. 3, 196" "si quis utendam rem acceperit eamque in alium usum transtulerit" - parece correta a idéia, estranha a Franco Pastori, de que o texto original do Ulp. 28 ad ed., D. 13, 6, 1, 1, afirmasse "utendi dati" 46

De qualquer forma, provavelmente foi a jurisprudência republicana, devido à presença de múltiplas relações em que o uti era mencionado, que intervém para distinguir o específico uti que ocorre por ato de benevolência do genérico uti do "utendum dare" 47

De qualquer forma, exceto a imprecisão terminológica, substancialmente, a alteração de "utendum dare" para "commodatum", no Direito Romano, manteve sempre a

caso concreto, pois a tutela in factum deveria ser expressa neste sentido.

44 SOLAZZI, Siro. Recensão ... cit., p. 258.

45 Gai 3, 196: "Itaque si quis re quae apud eum deposita sit, utatur, furtum committit. Et si quis utendam rem acceperit eamque in alium usum transtulerit, furti obligatur, ueluti si quis argentum utendum acceperit, quasi amicos ad cenam inuitaturus, et id peregre secum tulerit, aut si quis equum gestandi gratia commodatum longius aliquo duxerit, quod ueteres scripserunt de eo qui in aciem perduxisset." [= "Desta forma, o depositário que usa da coisa depositada comete furto. Também quem recebe uma coisa para certo uso (a título de comodato) e a emprega em outro diverso, responde por furto. Como, por exemplo, quem recebe uma baixela de prata para usar em uma ceia oferecida aos amigos, leva-a consigo em viagem; ou quem leva para longe o cavalo emprestado para montar, como os antigos se referiam àquele que levou o cavalo para a guerra"].

46 SOLAZZI, Siro. Recensão ... cit., p.. 258. Quanto menos acredita o autor que se possa determinar, com absoluta certeza que Pacônio foi o primeiro pretor a tutelar o comodato com uma actio decretalis. Siro Solazzi crê que Ulp. 28 ad ed., D. 13, 6, 1, 1, foi mais alterado do que é possível imaginar. O fato de Viviano ter admitido o comodato da gratuita habitatio pode ser considerada absurda, já que a palavra "amplius" na frase "Vivianus amplius etiam habitationem commodari posse ait" não poderia ter sido escrita pelo jurisconsulto, pois somente seria lógico este exemplo após o reconhecimento do comodato de coisas imóveis.

${ }^{47}$ Cf. PASTORI, Franco. Il commodato ... cit., p. 55. Assim, surgiu a necessidade de se distinguir formalmente o empréstimo de uso gratuito mediante uma denominação diferenciada que não o "utendum dare" Seria assim que, segundo a narração de Ulp. 28 ad ed., 13,6, 1, 1, quando a tutela do empréstimo de uso gratuito, por meio da actio decretalis, concedida pelo pretor, caso a caso, passou a ser tutelada por uma cláusula no Edito, que o pretor falaria em "commodare". As dúvidas de Labeão sobre a cláusula "De commodato" fazem pensar que esta não seria muito antiga e, considerando que Cícero não o mencionou como negócio jurídico, a tutela edital deve somente ter substituído a tutela ex decreto no fim da época republicana ou no início do Principado

Ao contrário, SOLAZZI, Siro. Recensão ... cit., p. 258, entende que, embora o comodato não gozava de tutela jurídica própria e se encontra no periodo republicano, o empréstimo de instrumentos e objetos domésticos era já muito comum e protegido juridicamente.

FERRARIO, G. A. Comodato. In: Enciclopedia Giuridica Italiana, 1930, v. 3, p. 385-386, considerando difícil estabelecer quando as actiones foram introduzidas no Direito Romano para tutelar o comodato, bem como quando teria mudado a denominação da fattispecie de "utendum dare" para "commodare", apenas afirma que, com certeza, no Direito Romano imperial o contrato de comodato apresenta-se como um contrato real bilateral imperfeito, pelo qual o devedor se obriga a restituir ao credor uma coisa não consumível e gratuitamente recebida para ser usada em um determinado fim, embora seja muito provável que a actio depositi e a actio commodati tenham sido criadas contemporaneamente, e pela actio depositi ser infamante, não poderia ter sido incluída no rol das ações infamantes existentes na Lex Iulia (45 a.C.). 
ideia de "beneficium tribuiere" [= "entregar o benefício"]: é graças ao comportamento do comodante que o vínculo jurídico eclode..$^{48}$

Resta, assim, o outro lado da moeda, ou seja, como aquele que recebe o favor irá responder.

\section{As gerações exegéticas de escritores sobre a responsabilidade do comodatário}

\section{1. A primeira geração exegética: a guerra entre custodia e culpa ${ }^{49}$}

Resolvida a autonomia do instituto, não tardaria para o foco da análise passar do "beneficium tribuere", que se refere ao comportamento do comodante e ao seu reconhecimento jurídico, para "custodiam praestare", expressão que se atém à responsabilidade do comodatário.

O estudo dessa última está compreendido no problema mais amplo da responsabilidade contratual no Direito Romano, um terreno fértil para as controvérsias ligadas ao comodatário, devido, inicialmente, aos fragmentos das Gai Institutiones (Gai. 3, 203-207), onde se encontra uma premissa ou um ponto de partida bastante seguro para a orientação da questão no período clássico. ${ }^{50}$

Da mesma forma, dentro da literatura jurídica, é possível distinguir uma primeira parte da doutrina que ou desenvolveu a responsabilidade do comodatário apenas entre os limites da culpa, ou realizou a mesma empreitada apenas no campo da custodia ${ }^{51}$

Conforme Franco Pastori, ${ }^{52}$ esta orientação iniciou-se com a glosa e seria retomada pelos pandectistas alemães.

48 Cf. ARANGIO-RUIZ, Vincenzo. Istituzioni ... cit., p. 314. A única diferença, fora a de caráter histórico, da maior antiguidade da expressão "utendum dare" e sua prevalência na linguagem extrajurídica enquanto a palavra "commodatum" seria consagrada no mundo jurídico - pode ser filológica. Neste sentido, considerando uma aplicação de ambas na prática e linguagem jurídicas, uma eventual tradução de "utendum dare" [= "dar para se servir; entregar o uso de algo"] focaliza no objeto do negócio jurídico, enquanto que "commodatum" invoca necessariamente, até mesmo devido à tradição jurídica que se enraizou na palavra, 0 elemento da gratuidade. Em outras palavras, elementos distintos da obrigação jurídica: o objeto da obrigação (a prestação) e a relação jurídica.

Também não pode ser deixado de lado o texto de Paul. 29 ad ed., D. 13, 6, 17, 3, pelo qual a entrega do beneficium constitui a entrada do comodato no mundo jurídico e assinala a natureza real do comodato. Cf., igualmente, FORCHIELLI, Paolo. op. cit., p. 2-5.

49 Deve-se reforçar que a divisão adotada em três gerações de escritores sobre a responsabilidade do comodatário tem como fundamento linhas gerais de entendimentos, sendo que possíveis variações internas em cada uma delas são absolutamente possíveis. O tempo determinado como vida útil de cada uma dessas gerações é aquele em que determinada(s) tese(s) prevaleceu(eram) e os autores mencionados são apenas os mais importantes para o seu argumento.

so PASTORI, Franco. Il commodato ... cit., p. 213-214.

51 PASTORI, Franco. Il commodato ... cit., p. 214-215.

52 PASTORI, Franco. Il commodato ... cit., p. 215-216. Segundo Franco Pastori, a idéia de bipolarizar a responsabilidade do comodatário, ou seja, somente a tratar nos limites da responsabilidade subjetiva (culpa), 
Essas duas tendências nítidas são encabeçadas, respectivamente, por Joham Christian Hasse ${ }^{53}$ e por Julius Baron. ${ }^{54}$ Ambos partem da premissa contida em Gai. 3, $206,{ }^{55}$ pelo o qual o comodatário "custodiam praestat", ${ }^{56}$ interpretando o que a palavra custodia viria a significar.

Esta primeira geração de escritores sobre a responsabilidade do comodatário, caracterizada por uma defesa radical ou da responsabilidade subjetiva, cujo maior representante é Joham Christian Hasse, ou da objetiva, comandada por Julius Baron, é marcada pela falta de um argumento histórico sistemático. ${ }^{57} \mathrm{Em}$ outras palavras, cada uma dessas teses imputa ao comodatário o parâmetro objetivo ou subjetivo de responsabilidade em todos os períodos do Direito Romano, não se permitindo uma eventual repartição dos critérios de responsabilidade em sua História Interna, ou seu eventual diálogo. ${ }^{58}$

ou apenas nos limites da responsabilidade objetiva (custodia em sentido técnico), seria seguida até mesmo por escritores do Direito Civil, como se vê pela adoção da tripartição do conceito da "culpa" "lata, levis, levissima" [basta cf., entre outros, a obra de POTHIER, Robert-Joseph. Traités du prêt a usage et du precaire. In: Euvre de Pothier (1844). 3. ed. Paris: Marchal et Billard, 1890, t. 5, p. 1-38 (= ns. 1-97), e de TROPLONG, Raymond-Théodore. Le droit civil expliqué - Du prêt. Paris: Charles Hingraus, 1845. t. 14, p. I-447 (= préface, n 1-500)] e, assim, consideram a responsabilidade do comodatário por meio de critérios subjetivos, embora elevem muitas vezes a diligência do comodatário a níveis jamais vistos, passando a compreender eventos, denominados casus minores, cujo conteúdo é estranho ao comportamento do comodatário [cf., entre outros, FERRARIO, G. A. op. cit., p. 385-405]. São duas tendências perceptíveis na tentativa de fundar a responsabilidade do comodatário pelo furto. A tendência geral apela para a culpa levissima, mas ainda existe a opinião, não tão acolhida, que esta responsabilidade teria natureza objetiva, onde se imputaria em absoluto a responsabilidade pelo risco.

HASSE, Joham Christian. op. cit., p. III-579 (= § 1-99).

44 BARON, Julius. Pandekten ... cit., p. 1-800 $(=\S 1-460)$. Nessa obra, de forma sintética.

s5 "Quae de fullone aut sarcinatore diximus, eadem transferemus et ad eum cui rem commodauimus. nam ut illi mercedem capiendo custodiam praestant, ita hic quoque utendi commodum percipiendo similiter necesse habet custodiam praestare." [= "O que dissemos sobre o tintureiro ou o alfaiate, aplicaremos também ao comodatário. Assim, como aqueles respondem pela custódia da coisa recebida (mediante restribuição), também é indispensável que este, que recebe a coisa para usá-la a título de comodato, responda igualmente por custódia."'].

56 Para MAYR, Robert. «Praestare». Zeitschrift der Savigny-Stiftung für Rechtsgeschichte - Romanistische Abteilung, v. 42, 1921, p. 199-200, 205-206, 213-216, 226-227, o verbo "praestare" permitiria uma tríplice acepção - "garantir, realizar ou responsabilizar" - e com essa uma nova dimensão de pesquisa para a expressão "custodiam praestare"

57 Salvo a tese de FERRINI, Contardo. Storia e teoria del contratto di commodato nel diritto romano. In: OPERE di Contardo Ferrini: Studi vari di diritto romano e moderno - Sulle obbligazioni, sul negozio giuridico, sulle presunzioni. Milano: Ulrico Hoepli, 1929. v. 3, p. 81-203 [= Storia e teoria del contratto di comodato nel diritto romano. Archivio Giuridico "Filippo Serafini", v. 52, p. 469-499, 1893 e v. 53, 1894, p. 41-73, 257-309].

58 Esta repartição de critérios entre os períodos da História Interna do Direito Romano seria conquista da segunda geração de escritores; e o eventual diálogo, embora germinado na segunda geração, é conquista definitiva da terceira geração de escritores. Cf. item 3. 2. e 3., infra.

Na primeira geração a defesa acalorada da responsabilidade subjetiva ou objetiva é tamanha que os próprios escritores, à época, se auto-repartiam em dois grupos. Cf. KRÜCKMANN, Paul. Custodia. Zeitschrift der Savigny-Stiftung für Rechtsgeschichte-Romanistische Abteilung, v. 64, 1944, p. 1-56 (= § 1-12). 
Ademais, essa primeira geração de escritores sobre a responsabilidade do comodatário, além de ser a mais longa das três gerações (começa no início do século XIX e se prolonga até meados do século XX), apresenta em sua maioria escritores alemães, ${ }^{59}$ presos ainda na metodologia das "caças às interpolações" - na qual o critério filológico prevalece sobre a análise histórica e dogmática.

Sem mais delongas, eis a primeira geração de escritores sobre a responsabilidade do comodatário. ${ }^{60}$

\section{1. 1. A defesa da responsabilidade subjetiva de Joham Christian Hasse}

Para Joham Christian Hasse ${ }^{61}$ o comodatário responde subjetivamente desde o período clássico até o fim do Direito Romano.

Seu raciocínio funda-se basicamente no sentido geral da bona fides que se impõe à conduta do comodatário, o qual responde por dolus et culpa, mas não por caso fortuito.

Segundo Franco Pastori, ${ }^{62}$ Joham Christian Hasse desejou compreender que o conteúdo da custodia seria uma medida da diligência na proteção da coisa emprestada, isto é, a custodia nada mais seria que uma species diligentiae [= "espécie de diligência"]. Assim, a custodia, nesses termos, pede um conceito de culpa, dentro do qual configura a responsabilidade do comodatário. ${ }^{63}$

Nesta linha, a expressão omne periculum [= "todo o risco"], prevista em Ulp. 28 ad ed., D. 13, 6, 5, 3, ${ }^{64}$ referiria-se a uma responsabilidade culposa do comodatário,

59 Salvo a obra de FERRINI, Contardo. op. cit., p. 81-203.

60 Conforme PASTORI, Franco. Il commodato ... cit., p. 229, a contraposição doutrinária que caracterizou, com maior ou menor intensidade, a matéria do comodato, entre a teoria da responsabilidade subjetiva e a da objetiva, é compreensível ao se considerar o regime que operava no dia-a-dia da responsabilidade do comodatário, por um lado, e a tradição romanística sobre a responsabilidade contratual, por outro.

${ }^{61}$ HASSE, Joham Christian. op. cit., p. 211-218.

62 PASTORI, Franco. Il commodato ... cit., p. 217

63 PASTORI, Franco. Il commodato ... cit., p. 217-218. Para este, a tentativa foi de tornar indissociável a custodia da culpa. Como a culpa é suscetível de graduações, pelo menos em "lata et levis", a partir deste vínculo indissociável, seria possível, pela tese de Joham Christian Hasse, também graduar a custodia em razão da diligência que se requer. Ao se falar apenas em diligentia estaria se falando do diligens paterfamilias, e, ao se falar em custodia, as fontes falariam da plena diligentia in custodiendo. Dentro deste paralelo perfeito apenas a responsabilidade do nauta, caupo et stabularius seria excepcional, por responderem pelo furto e pelos danos de outrem nas coisas a eles confiadas.

Segundo Franco Pastori, a tese de Joham Christian Hasse poderia sofrer uma segunda variação, já que o vocábulo "custodia" poderia apresentar dois significados: um, não-jurídico, como de proteção do objeto contra os eventos exteriores, e, um outro jurídico, da responsabilidade que deriva da falta desta proteção.

64 "Commodatum autem plerumque solam utilitatem continet eius cui commodatur, et ideo verior est Quinti Mucii sententia existimantis et culpam prestandam et diligentiam et, si forte res aestimata data sit, omne periculum praestandum ab eo, qui aestimationem se praestaturum recepit." [= "Em regra, é comum que no comodato exista utilidade (apenas) para o comodatário, e, por isso, é mais exata a opinião de Quinto Múcio, pela qual este (o comodatário) responde tanto por culpa, como por diligência. Além disso, se por 
e deveria ser interpretada como "omne periculum < culpae >" (enquanto reconstrução), o que significa que somente responde por vis maior se agiu culposamente em uma de três formas: usou ilicitamente da coisa, agiu imprudentemente, ou omitiu uma conduta que deveria ter realizado. ${ }^{65}$

Também para Paul Krückmann ${ }^{66}$ seria igualmente impossível a configuração da responsabilidade por custodia do comodatário no Direito Romano, onde teria prevalecido e vigorado a responsabilidade subjetiva, o que poderia ser fatalmente comprovado pelo fato que a mesma expressão "omne periculum" em Ulp. 28 ad ed., D. 13, 6, 5, 3, refere-se a uma responsabilidade subjetiva, ao prever a responsabilidade por caso fortuito. Assim, mesmo no período clássico, a responsabilidade já seria baseada na diligentia.

Da mesma forma, Gai. 2 aureor., D. 44, 7, 1, 4, ${ }^{67}$ preveria uma responsabilidade subjetiva pela exactissima diligentia custodiendae rei, e Ulp. 28 ad ed.,

acaso a coisa emprestada for estimada, aquele que aceitou suportar a avaliação responde (também) por todo o risco"].

65 HASSE, Joham Christian. op. cit., p. 211-218. Da mesma forma que em Ulp. 28 ad ed., D. 13, 6, 5, 3, também em Ulp. 28 ad ed., D. 13, 6, 5, 4, o substrato da responsabilidade seria, pelo autor, a culpa. Na fattispecie, o comodatário teria sua responsabilidade afastada quando escolheu salvar sua coisa mais valiosa em detrimento daquela do comodante, menos valiosa, uma vez que não teria agido, pela tese de Joham Christian Hasse, culposamente. A ponte entre os dois textos é justamente o fato de ambos tratarem da vis maior, que somente será imputada ao comodatário que agiu culposamente.

No mesmo sentido, FERRINI, Contardo. op. cit., p. 153-154, 156-164, defende que no caso de Ulp. 28 ad ed., D. 13, 6, 5, 4, que repete quase textualmente PS. 2, 4, 2, a responsabilidade seria igualmente subjetiva. Assim, o "princípio do sacrifício da coisa própria" seria uma hipótese decorrente da boa-fé.

Ulp. 28 ad ed., D. 13, 6, 5, 4: "Quod vero senectute contigit vel morbo, vel vi latronum ereptum est, aut quid simile accidit, dicendum est nihil eorum esse imputandum ei qui commodatum accepit, nisi aliqua culpa interveniat. proinde et si incendio vel ruina aliquid contigit vel aliquid damnum fatale, non tenebitur, nisi forte, cum possit res commodatas salvas facere, suas praetulit. " [= "Não deve ser imputado ao comodatário os acontecimentos que ocorrem por velhice ou por doença, ou mesmo quando a coisa é arrebatada por força de ladrões, ou se algo semelhante aconteceu, salvo se (o comodatário) não tiver intervido com alguma culpa. Portanto, (o comodatário) não estará obrigado se algo acontecer (à coisa emprestada) por incêndio, por ruína ou por qualquer outro dano fatal, salvo se podendo salvar as coisas dadas em comodato, preferiu as suas"]. Cf., também, VAZ SAMPAIO, Rodrigo Lima. Da Responsabilidade do Comodatário pelo Caso Fortuito ou de Força Maior - Acerca do Princípio do Sacrifício da Coisa Própria. Revista da Faculdade de Direito da Universidade de São Paulo, São Paulo, v. 103, p. 1.027-1.074, 2008.

66 KRÜCKMANN, Paul. op. cit., p. 16-19, 32-34

67 "Et ille quidem qui mutuum accepit, si quolibet casu quod accepit amiserit, nihilo minus obligatus permanet: is vero qui utendum accepit, si maiore casu, cui humana infirmitas resistere non potest, veluti incendio ruina naufragio, rem quam accepit amiserit, securus est. alias tamen exactissimam diligentiam custodiendae rei praestare compellitur, nec sufficit ei eandem diligentiam adhibere, quam suis rebus adhibet, si alius diligentior custodire poterit. sed et in maioribus casibus, si culpa eius interveniat, tenetur, veluti si quasi amicos ad cenam invitaturus argentum, quod in eam rem utendum acceperit, peregre proficiscens secum portare voluerit et id aut naufragio aut praedonum hostiumve incursu amiserit." ["E se o mutuário por qualquer acaso perder o que recebeu, não fica (por este) menos obrigado, mas certamente o comodatário fica isento de responsabilidade se perder aquilo que recebeu por força maior, evento este que a fraqueza humana não pode resistir, como, por exemplo, no caso do incêndio, da ruína ou do naufrágio. Em outras palavras, (o comodatário) deve responder pela exactissimam diligentiam custodiendae rei, já que não basta que ele preste a mesma diligência que tem com seus próprios bens, se puder custodiar a coisa emprestada 
D. $13,6,5,6,{ }^{68}$ seria descartado pelo autor como prova da responsabilidade por custodia, pelo fato que, logo no início, os veteres [= "juristas republicanos (antigos)"] teriam dúvida de sua configuração.

Contardo Ferrini ${ }^{69}$ acredita que a responsabilidade pode ser agravada em algumas circunstâncias, entre as quais a aestimatio prevista em Ulp. 28 aded., D. 13, 6, 5, 3.

Segundo Contardo Ferrini, a aestimatio somente pode ter dois sentidos, ou seja, o estabelecimento de um quantum indenizatório a ser pago na hipótese do comodatário agir culposamente, e o agravamento de sua responsabilidade. Mas tanto em um como em outro a aestimatio se submete à regra da utilitas, o que a faria se submeter igualmente aos ditames da responsabilidade subjetiva.

\section{1. 2. O ataque da responsabilidade por "custodia" de Julius Baron}

No extremo oposto, apoiado nos mesmos fragmentos - Gai. 3, 206, Ulp. 28 ad ed., D. 13, 6, 5, 3 e 4, e Gai. 2 aureor., D. 44, 7, 1, 4 - Julius Baron, ${ }^{70}$ em evidente oposição à tese de Joham Christian Hasse, ${ }^{71}$ afirma que o comodatário responde por custodia em todo o Direito Romano, ou seja, desde a tutela jurídica do comodato até o

com maior diligência. Mas, se o comodatário intervier com culpa, mesmo nas hipóteses de força maior, será responsável, como, por exemplo, se da mesma forma que convidou amigos para um jantar, recebeu para usar neste uma baixela de prata, e, querendo a levar em viagem ao exterior, esta se tivesse perdido em um naufrágio, em um assalto de bandidos ou em um ataque de inimigos"].

Segundo FERRINI, Contardo. op. cit., p. 153-154, 156-164, tanto em Gai. 2 aureor, D. 44, 7, 1, 4, como em Gai. 9 ad ed. provinc., D. 13, 6, 18 pr., esboçam-se hipóteses de responsabilidade subjetiva. A custodia não pode ser aqui entendida no sentido técnico que BARON, Julius. Pandekten ... cit., p. 427, 429-430 (= $\S$ 237), desejou.

68 "Sed an etiam hominis commodati custodia praestetur, apud veteres dubitatum est. nam interdum et hominis custodia praestanda est, si vinctus commodatus est, vel eius aetatis, ut custodia indigeret: certe si hoc actum est, ut custodiam is qui rogavit praestet, dicendum erit prestare." [= "Porém, entre os antigos há dúvida se (o comodatário) responderá ainda por custódia na hipótese de escravo entregue em comodato. De fato, algumas vezes (o comodatário) responderá pela custódia de um escravo, se (lhe) foi entregue em comodato um (escravo) preso, ou de (um escravo) idade avançada, que necessitasse de proteção. Seguramente, se for acordado que aquele que pediu em comodato responde por custódia, terá que se dizer que (este) a presta"]. Storia e teoria cit. (nota 41), p. 90-94, 186-191. Embora o argumento histórico esteja presente em seu texto, quanto à responsabilidade do comodatário, Contardo Ferrini é tão dogmático quanto os demais membros da primeira geração.

70 BARON, Julius. Pandekten ... cit., p. 429-430, 505 (= $§ 237$ e 275). Deve-se somente tomar cuidado que o conceito de custodia para J. Baron apresenta uma duplicidade inerente, podendo ser visto tanto pela perspectiva subjetiva como pela objetiva. A responsabilidade objetiva, como hoje a conhecemos, corresponde à custodia subjetiva ou técnica, enquanto a "custodia" objetiva ou atécnica não passa de responsabilidade subjetiva. Julius Baron defende a responsabilidade subjetiva ou técnica do comodatário. Assim, haveria uma ambiguidade inerente à palavra.

Cf., também, BARON, Julius. Die Haftung ... cit., p. 202-310; e BARON, Julius. Diligentia exactissima ... cit., p. 65-73, 88-92. Os coeficientes trocados dos conceitos a custodia subjetiva é a responsabilidade objetiva, e a objetiva a subjetiva - é próprio da confusão terminológica do século XIX.

${ }^{71}$ HASSE, Joham Christian. op. cit., p. 218. 
fim do período justinianeu, o comodatário responde objetivamente pelos danos causados à coisa emprestada.

Como bem observa Franco Pastori, ${ }^{72}$ a teoria de Julius Baron expõe como regra a responsabilidade excepcional para Joham Christian Hasse ${ }^{73}$ do nauta, caupo et stabularius, estendendo-a sobre uma série de relações jurídicas, entre as quais o horrearius, o conductor operis, o conductor operarum, o conductor de coisas móveis, o credor pignoratício, o negotiorum gestor, certos depositários, o devedor que deva adimplir a aestimatio rei, o vendedor e, em particular e com destaque, o comodatário.

Em todos estes casos, o devedor deve "custodiam praestare" e sua responsabilidade é limitada somente pela força maior "cui humana infirmitas resistere non potest" [= "evento o qual a fraqueza humana não pode resistir"]. ${ }^{74}$

Hermann Gottlieb Heumann e Emil Seckel ${ }^{75}$ entendem que culpa, no período justinianeu, pode significar custodia, porém, embora a culpa possa ter graduações, o mesmo não pode ocorrer com a custodia, sendo este um sinal distintivo de interpolação.

Além disso, subtende-se que uma interpolação não é apenas uma "forma de busca" do texto original, mas traz, em si, um significado. ${ }^{76} \mathrm{E}$, assim, culpa pode significar um critério de responsabilidade subjetiva, mas, em outros casos, ela somente retoma o conteúdo da custodia clássica, ou seja, nesta última hipótese, mudou-se o nome, mas não o conteúdo.

Heinrich Hackfeld Pflüger, ${ }^{77}$ às vésperas da publicação da obra de Franco Pastori, ${ }^{78}$ anuncia o desgaste desta primeira geração de escritores sobre o comodato, ao falar o óbvio, ou seja, que não mais é certo se as chaves da responsabilidade do comodatário estão no próprio Digesto (D. 13, 6: "Commodati [vel contra]"), e se esta seria subjetiva ou objetiva.

PASTORI, Franco. Il commodato ... cit., p. 217.

HASSE, Joham Christian. op. cit., p. 211-218.

74 É graças, como explica PASTORI, Franco. Il commodato ... cit., p. 218, à teoria de Julius Baron, que se pode falar de uma custodia com dois sentidos: um comum e atécnico, como sinônimo de obrigação de custodiar, e um particular e técnico, como responsabilidade objetiva, isto é, não se exige na custodia técnica uma simples diligentia, mas uma responsabilidade independente de qualquer diligentia in custodiendo. Esta última figura de responsabilidade que se contrapõe a neglegentia in custodiendo ou culpa in custodiendo.

75 HEUMANN, Hermann Gottlieb; SECKEL, Emil. Handlexicon zu den Quellen des römischen Rechts (1846). 9. ed. Jena: Gustav Fischer, 1926, p. 117-118. Em oposição ao desdobramento do raciocínio de Joham Christian Hasse.

76 HEUMANN, Hermann Gottlieb; SECKEL, Emil. op. cit., p. 117-118. Talvez para os pós-clássicos a mudança de nome seja mais uma aversão à responsabilidade objetiva clássica, do que propriamente medo. Mas, na prática, nada mudou do período clássico ao justinianeu.

77 PFLÜGER, Heinrich Hackfeld. Zur Lehre von der Haftung des Schuldners nach römischen Recht. Zeitschrift der Savigny-Stiftung für Rechtsgeschichte - Romanistische Abteilung, v. 65, 1947, p. 121. H. H. Pfüger considera que todos os autores que o precederam, levaram a discussão da responsabilidade do comodatário para o irracional, e o resultado é que não mais se poderia saber quem estaria certo.

78 PASTORI, Franco. Il commodato ... cit., p. XV-476. 
Mas, ainda apegado ao rigor conceitual e gramatical da primeira geração, Heinrich Hackfeld Pflüger 79 busca definir diligentia, não como "amare", mas como "Fleiß" [= "assiduidade, diligência"]. ${ }^{80} \mathrm{O}$ conceito de "Fleiß" seria capaz de aproximar o conceito de "culpa et diligentia" ao de "custodia" uma vez que a primeira expressão foi mera alteração justinianéia da segunda palavra, sem que com isso o padrão de responsabilidade do comodatário se alterasse. ${ }^{81}$

Ainda, Wolfgang Kunkel, ${ }^{82}$ identifica em Gai. 3, 203-207, a semente, ou a gênese da teoria do caso fortuito, que iria se aflorar no período justinianeu, bem como a presença da custodia como responsabilidade por alguns casos fortuitos. Segundo Wolfgang Kunkel, este critério de responsabilidade passaria por uma reorganização sob o critério da culpa, como teria ocorrido em Ulp. 5 ad ed., D. 19, 2, 41, mas não se pode afirmar que se tenha extinto a custodia por inteiro.

Nestas teses finais de Hermann Gottlieb Heumann e Emil Seckel, ${ }^{83}$ Heinrich Hackfeld Pflüger, ${ }^{84}$ e de Wolfgang Kunkel, ${ }^{85}$ embora exista a defesa de uma responsabilidade por custodia do comodatário nem época justinianéia, os próprios autores abriam exceções para a aplicação da culpa, amenizando o rigor da tese de Julius Baron.

Por fim, quanto ao aspecto processual, da primeira geração exegética de escritores sobre a responsabilidade do comodatário, Otto Lenel ${ }^{86}$ já demonstra um certo cepticismo, ao analisar a estrutura formular do comodato, em relação à possibilidade de um julgador poder avaliar um caso concreto através dos ditames da boa-fé - "nach Treu und Glaube" - e se afastando, assim, do direito escrito e vigente, do próprio ius civile,

79 PFLÜGER, Heinrich Hackfeld. op. cit., p. 123-124.

80 Utilizada pelo autor para explicar o sentido de diligentia, toda a tese de Heinrich Hackfeld Pflüger é desenvolvida sobre o conceito de "Fleiß", que pode ser traduzido como "diligência que o ser humano tem com as coisas que ama, e entre as quais estão aquelas sobre sua guarda". Não juigando se seu argumento é ou não a melhor forma para se explicar o conceito de diligentia, o fato é que com este argumento Heinrich Hackfeld Pflüger aproximou os institutos da diligentia, principalmente da diligentia custodiendae rei, e da custodia, passando a os tomar como sinônimos em vários trechos das fontes romanas, especialmente Ulp 28 ad ed., D. 13 6, 5, 3, e Gai. 2 aureor., D. 44, 7, 1, 4. No mesmo sentido, KUNKEL, Wolfgang. « Diligentia ». Zeitschrift der Savigny-Stiftung für Rechtsgeschichte - Romanistische Abteilung, v. 45, 1925, p. 268-269, 271-274, e 286.

81 Assim, PFLÜGER, Heinrich Hackfeld. op. cit., p. 132-133, defende, por meio da exegese de Gai 2 aureor., D. $44,7,1,4$, que a responsabilidade pelo furto da coisa emprestada, mesmo em período justinianeu, é objetiva, demonstrando que as expressões "diligentia custodiendae rei" e "custodia" são sinônimas. Tese esta que as interpolações feitas neste texto, como também em Gai. 9 ad ed. provinc., D. 13, 6, 18 pr., e em Inst. 3, 14, 2, somente reforçam. PFLÜGER, Heinrich Hackfeld. op. cit., p. 132-133, apenas considera hipóteses de responsabilidade subjetiva às inscritas em Ulp 28 ad ed., D. 13, 6, 5, 4 e 6. Este já pode ser visto como um sinal da gênese de uma nova geração exegética sobre a responsabilidade do comodatário.

82 KUNKEL, Wolfgang. op. cit., p. 268-269.

83 HEUMANN, Hermann Gottlieb; SECKEL, Emil. op. cit., p. 117-118.

84 PFLÜGER, Heinrich Hackfeld. op. cit., p. 121-218 (= §§ 1-8).

85 KUNKEL, Wolfgang. op. cit., p. 268-286.

86 LENEL, Otto. Das Edictum Perpetuum - Ein Versucht zu seiner Wiederherstellung (1883). 3 ed. Leipzig: Tauchnitz, 1927, p. $253(=\S 98)$. 
embora seja possível a reconstrução da formula in ius concepta do comodato a partir do exemplo de depósito descrito em Gai. $4,47,{ }^{87}$ e tomando como ponto de ligação Ulp. 28 ad ed., D. $13,6,3,2 .^{88}$

\section{2. A Geração "Histórica" do Comodato}

Se as teses de Heumann Gottlieb Heumann e Emil Seckel, Heinrich Hackfeld Pflüger, e de Wolfgang Kunkel, já demonstravam um desgaste sobre a defesa radical de uma ou outra forma de responsabilidade, por outro lado, o caráter "a-histórico" da primeira geração seria, em breve, fortemente contestado.

Vincenzo Arangio-Ruiz ${ }^{89}$ afirma que a forma com que Julius Baron e Joham Christian Hasse raciocinavam se baseava em uma excessiva confiança nas leis gerais da

87 "Sed ex quibusdam causis praetor et in ius et in factum conceptas formulas proponit, ueluti depositi et commodati. illa enim formula, quae ita concepta est ivdex esto. qvod a. agerivs apvd n. negidivm mensam argenteam deposvit, qva de re agitvr, qvidqvid ob eam rem n. negidivm a. agerio dare facere oportet ex fide bona, eivs ivdex n. negidivm a. agerio condemnato, nisi restituat. si non paret, absolvito, in ius concepta est. at iila formula, quae ita concepta est ivdex esto. si paret a. agerivm apvd n. negidivm mensam argenteam deposvisse eamqve dolo malo n. negiddii a. Agerio redditam non esse, qvanti ea res erit, tantam pecvniam ivdex n. negidivm a agerio condemnato. si non paret absolvito, in factum concepta est. similes etiam commodati formulae sunt." [ " "Mas, em certos casos, o pretor propõe fórmulas concebidas tanto in ius como in factum, como, por exemplo, (as) do depósito e (as) do comodato. Assim é concebida a fórmula in ius: (Tício) sê juiz. Como A. Agério depositou uma mesa de prata, que é o objeto desta ação, junto a N. Negídio, (o juiz) condena $\mathrm{N}$. Negídio em favor de A. Agério em tudo aquilo que, por causa do depósito, N. Negídio deve dar ou fazer de boa-fé face a A. Agério, salvo se restituir (a mesa depositada). Se não for evidente (que N. Negídio deva dar ou fazer de boa-fé), (o juiz o) absolve. Por outro lado, é também concebida a fórmula in factum: (Tício) sê juiz. Se for evidente que A. Agério depositou junto a N. Negídio e este, por dolo, não a tivesse restituído a A. Agério, o juiz condena N. Negídio a pagar a A. Agério no quanto valer a coisa (depositada). Se não for evidente (que N. Negídio não a tivesse restituído por dolo), (o juiz o) absolve. Certamente as fórmulas do comodato são semelhantes"].

88 "Nunc videndum est, quid veniat in commodati actione, utrum dolus an et culpa an vero et omne periculum. et quindem in contractibus interdum dolum solum, interdum et culpam praestamus: dolum in deposito: nam quia nulla utilitas eius versatur apud quem deponitur, merito dolus praestatur solus: nisi forte et merces accessit (tunc enim, ut est et constitutum, etiam culpa exhibetur) aut si hoc ab initio convenit, ut et culpam et periculum praestet is penes quem deponitur. sed ubi utriusque utilitas vertitur, ut in empto, ut in locato, ut in dote, ut in pignore, ut in societate, et dolus et culpa praestatur." [= "Vejamos agora se a ação de comodato se refere ao dolo, à culpa ou inclusive a todo o risco. Certamente, às vezes, nos contratos respondemos apenas pelo dolo, outra vezes também pela culpa; pelo dolo no depósito, uma vez que não há utilidade para o depositário, respondendo somente por dolo, a não ser que se arbitre algum aluguel (porque, neste caso, como se estabelece, se responde também pela culpa), ou se convenciono desde o primeiro momento que o depositário responda pela culpa e pelo risco; mas onde existe uma utilidade para as partes, como na compra, no arrendamento, no dote, no penhor, na sociedade, se responde não somente pelo dolo, como também pela culpa"].

89 ARANGIO-RUIZ, Vincenzo. Responsabilità ... cit., p. 76-79. Segundo Vincenzo Arangio-Ruiz, as teses de Julius Baron e de Joham Christian Hasse inseriam-se em um periodo no qual as indagações interpolacionistas eram amplamente difundidas, e, por este motivo, chegou-se ao absurdo de se sustentar que no período clássico, sempre se respondia subjetivamente, e, no justinianeu, objetivamente. Que hoje o movimento da doutrina em direção à responsabilidade objetiva se inspira pelas necessidades crescentes do comércio é a mais pura verdade. Mas, a partir disto não se pode afirmar a origem desta responsabilidade onde e quando 
evolução jurídica, tornando-se teses meramente aproximativas da realidade e que contam com incontáveis exceções.

E devido a essas diversas ressalvas, não haveria mais como se sustentar que o comodatário teria respondido, durante todo o Direito Romano, ou subjetivamente ou objetivamente.

Os precursores da segunda geração de escritores sobre a responsabilidade do comodatário ${ }^{90}$ acabaram por chegar a uma conclusão diversa, que se tornaria a tese dominante até os dias atuais: o comodatário responderia objetivamente - pela figura técnica da custodia -- no período clássico e responderia subjetivamente baseada na diligentia/culpa - na época justinianéia. ${ }^{91}$

A responsabilidade do comodatário passa a variar com os períodos da História Interna do Direito Romano (o que poderia ser, a grosso modo, uma mistura das duas vertentes da primeira geração de escritores), e a predominância do pensamento alemã cederia seu espaço para os doutrinadores italianos.

\subsubsection{A Doutrina "Pré-" e "Pós-" Franco Pastori}

Conforme a tese de Giuseppe Ignazio Luzzatto, ${ }^{92} \mathrm{o}$ comodatário responderia por custodia no período clássico, por culpa no direito pós-clássico, e por diligentia

bem se pretender.

A custodia romana era considerada adequada às relações mais básicas da vida romana, como aquela desenvolvida com o tintureiro, com o alfaiate e com o comodatário. São sempre contratos extremamente elementares e em círculos cada vez mais humildes, como a da classe dos pastores, o que leva à conclusão de que o instituto seja tão antigo quanto a própria história de Roma. Porém, mesmo se o desejo fosse seguir a idéia de Julius Baron, segundo o qual a responsabilidade por custodia também representa o expoente de maior desenvolvimento do comércio, esta não poderia ser reconhecida, unanimemente, na época de Justiniano. E, pelo contrário, não haveria ambiente melhor para seu desenvolvimento que o dos primeiros séculos do Império, e nenhum mais inadequado que o bizantino.

Afinal, o incremento do comércio não ocorre em uma linha uniforme de progresso, e a decadência do mundo antigo mostra que existia uma intensa atividade comercial na época dos Flávios e dos Antoninos, mas, em seguida, sucederia uma crise jamais equiparável, inclusive na época bizantina, onde a vida econômica se restringe aos parâmetros da Idade Média.

90 Cf. especialmente LUZZATTO, Giuseppe Ignazio. Caso fortuito ... cit., p. 1-265, e ARANGIO-RUIZ, Vincenzo. Responsabilità ... cit., p. 62-99.

91 A obra máxima da segunda geração e que marcaria definitivamente seu início viria em 1954. Trata-se da monografia de PASTORI, Franco. Il commodato ... cit., p. XV-476.

92 LUZZATTO, Giuseppe Ignazio. Caso fortuito ... cit., p. 117-131. A tese Giuseppe Ignazio Luzzatto detém dois eixos centrais: o primeiro é a teoria do caso fortuito e o segundo é a evolução dos critérios da responsabilidade do comodatário durante a história romana. Segundo esta tese não seria possível dissociar um argumento do outro. Desta forma, não existiria para o autor a possibilidade do comodatário responder objetivamente no direito justinianeu, uma vez que já se teria completado a evolução da responsabilidade objetiva para a subjetiva em seu último estágio, isto é, a graduação da diligentia conforme a regra abstrata da utilitas e da diferenciação entre casus minor e casus maior. 
exactissima no período justinianeu, sendo que somente neste último seria possível vislumbrar com exatidão a graduação dos critérios da culpa.

Esta evolução somente pode ser percebida devido à perceptível tríplice estratificação pela qual Inst. 3, 14, 2, e Gai. 2 aureor., D. 44, 7, 1, 4, teriam passado: uma realizada pelo próprio Gaio no período clássico, outra no direito pós-clássico, e, por fim, uma na compilação justinianéia. ${ }^{93}$

A suposição de diversas estratificações em alguns textos, em especial Inst. 3, 14, 2, ${ }^{94}$ e Gai. 2 aureor., D. 44, 7, 1, 4, teria como intenção evitar as antinomias que aparecem entre eles, acabando por provocar o desgaste da primeira geração de escritores sobre a responsabilidade do comodatário. ${ }^{95}$

93 Esta tripla evolução da responsabilidade do comodatário poderia ser vislumbrada nesses dois textos pelo fato de que Inst. 3, 14, 2, aproxima-se mais do período pós-clássico, enquanto que Gai. 2 aureor., D. 44, $7,1,4$, já se insere plenamente na época justinianéia, onde a responsabilidade subjetiva do comodatário teria chegado ao maior refinamento. São possíveis de identificar duas falhas no raciocínio de Giuseppe Ignazio Luzzatto. A primeira é desejar atribuir a responsabilidade pelo caso fortuito como conexa à por culpa, já que, a figura da custodia é, ainda no período clássico, conceitualmente a responsabilidade por determinados eventos fortuitos, o que já pressupõe uma distinção entre casus minor e casus maior e somente poderia ter ocorrido implicitamente com Justiniano, e explicitamente no direito bizantino. A segunda referese à conexão realizada entre a utilitas e a diligentia exactissima do comodatário. Para Giuseppe Ignazio Luzzatto, parece que o comodatário responde sempre por esta última, o que contraria a regra da utilitas, pela qual o comodatário somente responderia pela diligentia exactissima quando fosse o único a obter os proveitos e deter interesses sobre a relação contratual. Logo, a diligentia exactisisma somente pode obter o valor desejado por Giuseppe Ignazio Luzzatto, quando dentro da fattispecie estiver claramente determinado apenas os interesses exclusivos do comodatário no negócio jurídico. Teria que se submeter a análise de cada fragmento à busca se, no caso narrado pelo jurista romano, somente o comodatário tem interesses no negócio.

94 "Item is cui res aliqua utenda datur, id est commodatur, re obligatur et tenetur commodati actione. sed is ab eo, qui mutuum accepit, longe distat: namque non ita res datur, ut eius fiat, et ob id de ea re ipsa restituenda tenetur. et is quidem qui mutuum accepit, si quolibet fortuito casu quod accepit amiserit, veluti incendio, ruina, naufragio aut latronum hostiumve incursu, nihilo minus obligatus permanet. at is qui utendum accepit sane quidem exactam diligentiam custodiendae rei praestare iubetur nec sufficit ei tantam diligentiam adhibuisse, quantam suis rebus adhibere solitus est, si modo alius diligentior poterit eam rem custodire: sed propter maiorem vim maioresve casus non tenetur, si modo non huius culpa is casus intervenerit: alioquin si id quod tibi commodatum est peregre ferre tecum malueris et vel incursu hostium praedonumve vel naufragio amiseris, dubium non est quin de restituenda ea re tenearis. commodata autem res tunc proprie intellegitur, si nulla mercede accepta vel constituta res tibi utenda data est. alioquin mercede interveniente locatus tibi usus rei videtur: gratuitum enim debet esse commodatum." [= "O comodatário, que recebe de uma coisa para dela se servir, fica obrigado pela tradição e responde pela ação de comodato. Ele difere muito do mutuáiro, pois, quando recebe a coisa, não se torna dono, e deve restituir a mesma coisa que recebeu. (Ao contrário,) $\mathrm{O}$ mutuário que perde a coisa por um caso fortuito, como, por exemplo, por incêndio, ruína, naufrágio, ataque de ladrões ou de inimigos, continua, da mesma forma, obrigado. Já o comodatário, ainda que deva responder por exactam diligenitam custodiendae rei, não bastando a mesma diligência que tem com suas coisas, se outra pessoa mais cuidadosa poderia ter evitado a perda, mas não responde por fortuito ou força maior ocorridos sem sua culpa. Porém, se levares em viagem a coisa que te foi entregue em comodato, e a perderes, seja em um ataque de inimigos ou de ladrões, seja em um naufrágio, ficas obrigado a restituí-la. $O$ comodato existe tecnicamente quando se recebe uma coisa para dela se utilizar sem remuneração alguma; se esta houver, existe locação do uso da coisa, já que o comodato deve ser gratuito"].

PASTORI, Franco. Il commodato ... cit., p. 219. 
Trata-se de uma posição que não é diversa do entendimento de Vincenzo Arangio-Ruiz ${ }^{96}$, embora este seja menos categórico no conteúdo da responsabilidade do comodatário e na divisão entre os períodos clássico e justinianeu. ${ }^{97}$

Vincenzo Arangio-Ruiz ${ }^{98}$ trabalha com a hipótese de que o Gaio de Gai. 3, 205-207, seria o original, enquanto o de Gai. 2 aureor., D. 44, 7, 1, 4, seria falsificado, ou, em outros termos, o texto não teria sido uma obra propriamente de Gaio.

Mais do que um texto, como seria exatamente Ulp. 28 ad ed., D. 13, 6, 5, 3, que teria passado por três estratificações, Gai. 2 aureor., D. 44, 7, 1, 4, seria, na realidade, um texto que foi escrito em época bizantina e acabaria por ser inserido no Corpus Iuris Civilis, ou seja, teriam os compiladores unida a parte referente à responsabilidade de Gai. $3,205-207$, com os contratos reais previsto nas "Res Cotidianae" [= "Assuntos do Dia-adia"']. 99

Em seguida, a tese de Franco Pastori ${ }^{100}$ iria se tornar um divisor de águas na doutrina.

Ela se fundamenta em dois aspectos, um, de índole processual, acerca da duplicidade formular da actio commodati, e outro, de caráter substancial, sobre a responsabilidade contratual no comodato, tanto do comodatário, como do comodante ${ }^{101}$

Logo, esses dois aspectos - processual e substancial - tornariam-se argumentos chaves para a construção de uma tese sobre a responsabilidade do comodatário.

Do ponto de vista processual, Franco Pastori ${ }^{102}$ acredita que a própria estrutura das actiones determina um critério de responsabilidade específico: enquanto a actio in factum se refere ou conduz à custodia, a actio in ius proporcionaria a tutela da "culpa"

Assim, historicamente, Franco Pastori sustenta que, embora no início do período clássico a actio in factum tenha sido a única a tutelar o comodato, apenas dois

96 ARANGIO-RUIZ, Vincenzo. Responsabilità ... cit., p. 62-99.

97 PASTORI, Franco. Il commodato ... cit., p. 219-220.

98 ARANGIO-RUIZ, Vincenzo. Responsabilità ... cit., p. 62-99.

99 ARANGIO-RUIZ, Vincenzo. Responsabilità ... cit., pp. 62-99. Embora Vincenzo Arangio-Ruiz acredite que exista uma responsabilidade subjetiva ao se referir à exactissima diligentia custodiendae rei, haveria uma contradição insanável entre a exactissima diligentia, posta como critério da responsabilidade do comodatário, e a constatação de que este somente se liberta da responsabilidade pelo casus maior cui resisti non potest. E a saida que se tem para solucionar a questão cria uma presunção de culpa em todas as hipóteses, exceto a força maior, o que, por um lado, demonstra a ojeriza dos bizantinos pela responsabilidade objetiva, mas, na prática, a custodia continua vigente.

100 PASTORI, Franco. Il commodato ... cit., p. XV-476. Sua tese recupera muitos argumentos de LUZZATTO, Giuseppe Ignazio. Caso fortuito ... cit., p. 1-265, e de ARANGIO-RUIZ, Vincenzo. Responsabilità ... cit.,, p. $62-99$, mas vai muito mais além, uma vez que, diferentemente de seus precursores, ele somente se deteve no comodato, e abre "brechas" para o desenvolvimento da terceira geração de escritores (como a possibilidade da culpa e da custodia terem convivido como critérios de responsabilidade no direito pós-clássico romano).

PASTORI, Franco. Il commodato ... cit., p. 95-148. 
séculos depois, ainda neste, seria concedida a tutela pela actio in ius, quando o instituto já gozava de certo desenvolvimento.

Assim, durante grande parte do clássico e todo o período pós-clássico, essas duas ações conviveram, sendo que somente no justinianeu elas teriam se unificado sob a predominância da actio in ius.

Do ponto de vista substancial, ${ }^{103}$ a tese sustenta que, no período clássico, por força das Gai Institutiones (Gai. 3, 206), o comodatário somente respondia por custodia, sendo que, no pós-clássico, este critério concorreria com o da culpa. ${ }^{104}$

Por fim, com Justiniano, somente se responderia por culpa, estando presente o fenômeno denominado de "decadência da custodia" Assim, somente no período pósclássico existiria uma responsabilidade multifacetada, baseada ora na culpa, ora na custodia.

Após a publicação de sua tese, Franco Pastori sofreria, nos anos seguintes, a mais forte reação que viria a existir na história da responsabilidade do comodatário, e do próprio instituto. Somente após o fim dessa, sua importância determinaria uma sobre-vida da segunda geração em toda uma vertente da terceira geração de escritores. ${ }^{105}$

103 PASTORI, Franco. Il commodato ... cit., p. 199-416. O mérito de sua tese frente à de Giuseppe Ignazio Luzzatto e Vincenzo Arangio-Ruiz seria justamente uma análise detalhada da passagem do critério da custodia para o da culpa. Por outro lado, nos parece que, ao se conflitar os dois argumentos - processual e substancial -, o pensamento desenvolvido por Franco Pastori não seria plenamente coerente, salvo no período pós-clássico onde os dois argumentos se casam plenamente. Essa falha pode ser percebida quanto ao período clássico, onde Franco Pastori afirma existir apenas a responsabilidade por custodia, mas acredita que já teria sido criada a tutela in ius; e, quanto ao justinianeu, onde apenas teria sobrevivido a formula in ius concepta, restam indícios de que substancialmente Franco Pastori acredite na sobrevivência da custodia, enquanto critério de responsabilidade. Ele mesmo afirma [PASTORI, Franco. Il commodato ... cit., p. 223] que, nesse último período, pela própria actio in ius, devido à dificuldade de se fazer a prova, dentro de uma responsabilidade culposa, esta somente teria mera importância teórica, resolvendo-se a questão por meio da presunção da culpa. A responsabilidade subjetiva tornar-se-ia, na prática, objetiva.

104 Segundo PASTORI, Franco. Il commodato ... cit., p. 223-224, o ponto de partida para a tradição da culpa, no direito justinianeu, encontra-se em Ulp. 28 ad ed., D. 13, 6, 5, 2, onde Ulpiano retoma a regra da utilitas, de autoria de Stefano. O jurisconsulto teria distinguido os casos em que a utilidade do contrato é para ambas as partes, e onde ambos respondem por dolus, culpa, custodia, e quando só o comodatário ou o comodante auferisse o benefício, assim, somente quem recebeu o benefício responde por dolus, culpa, custodia e diligentia. Assim, se apenas o comodatário auferisse o benefício do contrato, ele deve ter uma diligentia específica, isto é, que uma pessoa mais que escrupulosa teria - vir diligentissimus - nos próprios assuntos. Essa diligentia poderia ser denominada de custodia, que, obviamente, não gozaria de um significado técnico, sentindo-se, assim a necessidade de se falar em custodia simples, ou atécnica, e custodia qualificada, ou técnica. Fala-se da responsabilidade do comodatário dentro dos limites subjetivos, e somente requer deste uma diligência para conservar a coisa, uma custodia atécnica. Assim, a custodia é colocada entre os limites da culpa-culpam sive custodiam -, podendo aquela, como esta, sofrer graduações.

105 De fato, a obra de Franco Pastori ganharia tamanha força que uma parte inteira dos escritores que a ele se seguiram, somente repetiriam suas palavras, nada acrescentando ao tema. Pode-se inclusive questionar se esses escritores constituiriam uma nova geração no tema, ou mero copistas da tese de Franco Pastori. Cf. item 3. 3., infra. 
3.2.2. Todos contra Franco Pastori: as reações de Siro Solazzi, Giuseppe Ignazio Luzzatto, e Vojtech Polácek ${ }^{106}$

As reações mais fortes, em ordem de importância, que a tese de Franco Pastori sofreria, seriam as de Siro Solazzi, Giuseppe Ignazio Luzzatto, e Vojtech Polácek. ${ }^{107}$

Em 1955, Siro Solazzi ${ }^{108}$ lança duas críticas - ambas na revista IURA (Rivista Internazionale di Diritto Romano e Antico) - sobre a obra de Franco Pastori. ${ }^{109}$

Em primeiro lugar, Siro Solazzi ${ }^{110}$ acredita que as conclusões de Franco Pastori já tinham sido alcançadas por Vincenzo Arangio-Ruiz ${ }^{111}$ e por Giuseppe Ignazio Luzzatto, ${ }^{112}$ sendo que Franco Pastori não trouxe nenhum argumento novo, muito menos resultados originais, embora assim tivesse prometido. ${ }^{113}$

Da mesma forma, Siro Solazzi ${ }^{114}$ acusa Franco Pastori de não trazer qualquer "contributi allo studio della responsabilità contrattuale" [= "contribuição ao estudo da responsabilidade contratual"'], justamente o subtítulo da primeira edição de sua obra.

Siro Solazzi115 alega ser de notório conhecimento que, enquanto grande parte da doutrina pandectista construía a responsabilidade com base no dolus e na culpa, ${ }^{116}$ os autores, em meados do século XX, sustentam que os critérios de responsabilidade, no período clássico, somente poderiam ser o dolus e a custodia. ${ }^{117}$

Portanto, mais uma vez a crítica de falta de originalidade da tese de Franco

Pastori. 118

106 Este tópico se deterá apenas em relatar as reações doutrinárias, que na maior parte das vezes desaguou em disputas pessoais. Os aspectos dogmáticos referentes à duplicidade formular e à responsabilidade por custodia do comodatário estão descritos com maiores pormenores em VAZ SAMPAIO, Rodrigo Lima. Da Responsabilidade Objetiva do Comodatário no Direito Romano. In: RevFADUSP (Revista da Faculdade de Direito da Universidade de São Paulo), 2009, 104, p. 771-840. POLÁCEK, Vojtech. op. cit., p. 161-184.

108 SOLAZZI, Siro. Recensão ... cit., p. 258-270, e SOLAZZI, Siro. La responsabilità del commodatario nelle Istituzioni di Gaio. IURA: Rivista Internazionale di Diritto Romano e Antico, v. 6, p. 139-145, 1955.

109 PASTORI, Franco. Il commodato ... cit., p. XV-476.

110 SOLAZZI, Siro. La responsabilità ... cit., p. 139.

111 ARANGIO-RUIZ, Vincenzo. Responsabilità ... cit., p. 1-281.

112 LUZZATTO, Giuseppe Ignazio. Caso fortuito ... cit., p. 1-265.

113 As críticas de SOLAZZI, Siro. La responsabilità ... cit., p. 139-140, voltam-se primeiro para a análise que Franco Pastori realiza sobre Gai. 3, 207, quanto ao penhor. A actio furti não cabe ao proprietário da coisa penhorada, ou seja, ao devedor, uma vez que não se deveria traduzir literalmente "id est ipse debitor" [= "isto é o próprio devedor"]. Lembra-se ainda que de costume o penhor é concedido pelo devedor, mas nada impede que um amigo deste, ou seja, um terceiro preste a garantia pelo devedor. SOLAZZI, Siro. Recensão ... cit., p. 258.

115 SOLAZZI, Siro. Recensão ... cit., p. 261-262.

116 Cf. primeira geração de escritores sobre a responsabilidade do comodatário, sob o domínio da tese de Joham Christian Hasse, no item 3. 1. 1., supra.

117 SOLAZZI, Siro. Recensão ... cit., p. 262, sustenta que mesmo esta doutrina é questionável, pois não é mais unânime a opinião de que se atribui somente e sempre na hipótese de furto uma responsabilidade objetiva. SOLAZZI, Siro. Recensão ... cit., p. 270, termina sobre o domínio de um estranho silêncio. Esse legitima o 


\section{A resposta de Franco Pastori ${ }^{119}$ viria a galope.}

Franco Pastori diz se assustar que Siro Solazzi tenha tentado invalidar em absoluto os seus resultados na reconstrução da responsabilidade do comodatário, sem considerar adequadamente a problemática que se impõe pelas fontes. ${ }^{120}$

No último parágrafo de sua defesa, Franco Pastori ${ }^{121}$ afirma não se iludir que seu trabalho sobre o comodato e a responsabilidade contratual seja completo e imune de defeitos, e diz compreender Siro Solazzi quando lhe imputa um "strano silenzio" [= "estranho silêncio"] por não aprofundar em algumas exegeses, que teriam completado o trabalho, mas não aceita, após ter este último aceito toda sua tese reconstrutiva, atacá-lo com frases injustificáveis e inúteis, como "il silenzio è d'oro" [ = "o silêncio vale ouro"] e "strane" [= "estranhas"]. ${ }^{122}$

A réplica viria em 1957, em um artigo científico com o irônico título "Una favola su Gai 3.204" [= "Uma Fábula sobre Gai. 3,204"].123

Logo, em seu início, Siro Solazzi ${ }^{124}$ afirma que esta seria a última vez que falaria desta "opera infelice" [= "obra infeliz"] de Franco Pastori.

juízo negativo sobre o livro, o qual teve a infelicidade, para Siro Solazzi, de ser a estréia das publicações da Facoltà do Giurisprudenza dell' Universittà degli Studi di Urbino, já que no futuro seria facilmente superado. PASTORI, Franco. Gaio e la responsabilità contrattuale. Labeo (Rassegna di Diritto Romano), v. 2, 1956, p.. 291-326.

120 PASTORI, Franco. Gaio ... cit., p. 325-326. A surpresa torna-se ainda maior para Franco Pastori, uma vez que as críticas levantadas não objetivam tornar mais bela e rica a matéria, mas, pelo contrário, desafiam inimigos imaginários como o problemático amicus do devedor escondido em Gai. 3, 204; a custodia entendida como contra-prestação no comodato e na locatio operis, na qual são parte o fullo e o sarcinator; a utilitas contrahentium entendida como regra abstrata e colocada com relação à legitimidade da actio furti de Gai. 3, 206; a obscura - na realidade, imbecil - semelhança entre as formulae do comodato e do depósito, em Gai. 4, 47; e, por fim, a distinção inútil entre a responsabilidade por custodia e o dever de vigilância do comodatário na fuga do escravo, em Ulp. 28 ad ed., D. 13, 6, 5, 6.

121 PASTORI, Franco. Gaio ... cit., p. 326. Franco Pastori encerra seu artigo e defesa pedindo desculpas, pois se "l'umano amore per le mie opinioni ha talvolta accentuato l'ardore nella loro difesa. Sono certo che Egli mi potrà comprendere: dopo tutto, il mio ardore nella difesa prova l'impegno nel meditare le Sue critiche, allo stesso modo che l'ardore delle Sue critiche prova la seria e immeritata considerazione fatta al mio lavoro. E di questo sono grato al Maestro"

122 SOLAZZI, Siro. Recensão ... cit., p. 270

${ }_{123}$ Cf. SOLAZZI, Siro. Una favola su Gai 3.204. Labeo (Rassegna di Diritto Romano), v. 3, 1957, p. 89-92. Trata-se mais de um encerramento de discussão - como o nome "favola" alude à sua discussão acadêmica com Franco Pastori - do que um artigo científico relevante. O próprio texto de Gai. 3, 204, que dá nome ao artigo, é tratado com pouca brevidade.

124 SOLAZZI, Siro. Una favola ... cit., p. 89. Em um nítido desabafo, Siro Solazzi conta o inimaginável sofrimento que teve de passar por ter aceitado o envio de uma cópia do livro Franco Pastori pelo corpo editorial da revista IURA com o objetivo de realizar uma recensão. Primeiro, ele teria que ter resistido a "lettura asfissiante" de 424 páginas de raciocínio falho, inútil ou insignificante, para, em seguida, suportar um jogo maçante de longuíssimas e violentas discussões, resistindo aos ataques constantes de um autor que explodia de raiva. Siro Solazzi decide, assim, terminar a discussão sobre a obra, competência e talento duvidosos de Franco Pastori. Não deseja torna a questão um motivo de diversão, acrescentado cada vez mais "pimenta", como se fosse construir uma réplica. Enfim, o autor não sente a necessidade "di mostrare che nei tardi anni e coi mali degli anni ho ancora dovizia di spirito polemico" 
Desta forma, o ataque tornou-se pessoal e Siro Solazzi aconselha aos leitores que todas as interpretações feitas por Franco Pastori quanto às fontes romanas, principalmente, aquelas relativas às Gai Institutiones, além de muito mal organizadas, não são em nada aconselháveis, já que realizadas por um péssimo exegeta.

Também farpas pessoais e não científicas seriam o foco da controvérsia entre Giuseppe Ignazio Luzzatto ${ }^{125}$ e Franco Pastori.

Sobre dois tópicos centrais - a duplicidade formular e a responsabilidade por custodia - recaem a crítica de Giuseppe Ignazio Luzzatto. ${ }^{126}$

Giuseppe Ignazio Luzzatto entende que tanto a actio in ius, quanto a actio in factum têm o mesmo objeto: a devolução da coisa emprestada.

Em outras palavras, não teriam escopos diversos como desejava Franco Pastori ${ }^{127}$ : pelo qual primeiro deveria se mover a actio in factum para pedir a devolução da coisa, e depois a actio in ius, onde o comodante conseguiria uma indenização.

125 LUZZATTO, Giuseppe Ignazio. « Commodati... vel contra ». Labeo (Rassegna di diritto romano), v. 2, 1956, p. 357-362. Essa discussão teve uma origem diversa daquela ocorrida com Siro Solazzi. Franco Pastori publica um estudo altamente polêmico e irônico [PASTORI, Franco. Sulla duplicità formulare dell'« actio commodati ». Labeo (Rassegna di Diritto Romano), v. 2, 1956, p. 89-94] contra Emilio Betti e Giuseppe Ignazio Luzzatto, "viribus unitis", para defender sua tese sobre comodato em alguns pontos que estes dois autores, minoritariamente, esboçaram em um relatório para o concurso da cátedra de Direito Romano da Università de Bari, contido no Bollettino Ufficiale del Ministerio della Pubblica Istituzione, de 1955. Tratase de um Bollettino institucional e que não deveria ter sido usado com propósitos científicos.

Existem alguns antecendentes interessantes dessa controvérisa de serem narrados. No famoso concurso para a cátedra de professor titular de Direito Romano da Università di Bari, a Comissão deste propôs, em maioria, ao Ministerio della Pubblica Istruzione, uma lista tríplice, formada por Santi Di Paola, Francesco Maria De Robertis e Franco Pastori. Contra essa proposta, os professores Emilio Betti e Giuseppe Ignazio Luzzatto apresentaram, em minoria, uma relação detalhada dos motivos da já muito conhecida desaprovação na formação dessa lista tríplece, bem como da preferência dada a Franco Pastori frente aos demais candidatos, que seriam, na opinião desses professores muito mais merecedores da cátedra que este último. Assim, não seria aceita a candidatura do terceiro membro, Franco Pastori, e seriam aprovadas, em 24 de dezembro de 1954, as atas da Comssião, cristalizando a candidatura dos outros dois candidatos. É contra a resposta desse concurso que a reação de Franco Pastori virou-se. Giuseppe Ignazio Luzzatto demonstra, na realidade, nem saber se seria o caso de reagir ao ataque de Franco Pastori, crítica sem precedentes na história das Universidades Italianas, por parte de um candidato, que polemizou em uma revista científica - a Labeo (Rassegna di Diritto Romano) - a decisão de um concurso. Essa dúvida não se encontra somente por se arrastar polemicamente para um juizo de mérito de uma decisão em si irrecorrível, que é a decisão de toda comissão de concurso universitário, e não somente de sua minoria. Mas também porque, além disso, atacaram-se diretamente dois membros dessa comissão na suas funções de funcionários e de juízes e se violou o próprio iter que se tem em um concurso deste nivel.

Todas as críticas feitas a Franco Pastori investiam contra a produção científica do candidato, o que demonstra que essas não se limitaram apenas contra a tese deste autor sobre o comodato. Vale ainda a ressalva que apenas Giuseppe Ignazio Luzzatto respondeu brevemente às críticas realizadas contra a minoria do concurso, e Emilio Betti não o fez.

126 LUZZATTO, Giuseppe Ignazio. « Commodati ... cit., p. 357-362.

127 PASTORI, Franco. Il commodato ... cit., p. 95-148. Além disso, Franco Pastori sustenta que a actio in factum exterioriza uma responsabilidade por custodia, o que não poderia ser feito pelo iudicum bonae fidei. Partindo da ideia que qualquer das ações visa à devolução da coisa emprestada, LUZZATTO, Giuseppe Ignazio. « Commodati ... cit., p. 357-362, entende que também no iudicium bonae fidei poderia-se demandar 
Assim, afastada a tese de Franco Pastori, o comodante poderia escolher qualquer das duas ações, que seria suficiente para seu objetivo, o que poderia levar ao desaparecimento da actio in factum.

Faltaria também na tese de Franco Pastori um coerente diálogo entre o aspecto processual e os critérios de responsabilidade, uma vez que, para Giuseppe Ignazio Luzzatto, ${ }^{128}$ não existiria propriamente uma duplicidade formular com a rigidez que Franco Pastori desejou, podendo a responsabilidade por custodia ser demandada por ambas as fórmulas.

Por fim, existe uma controvérsia com Vojtech Polácek ${ }^{129}$ quanto ao método utilizado por Franco Pastori.

Segundo Vojtech Polácek ${ }^{130}$ as pesquisas científicas, mesmo no campo das ciências sociais, presenciam uma evolução contínua, pois, caso contrário, bastaria à ciência a existência de apenas uma obra sobre a qual todos os pesquisadores acordassem, e que seria constantemente reproduzida no tempo.

O melhor método a ser seguido somente pode ser o "dogmático", entendido como "materialismo histórico", por meio do qual se isolam fenômenos particulares para os descrever estaticamente, construindo uma base ou um sistema para a solução do problema que algumas vezes já poderia ser antecipado. ${ }^{131}$

O método utilizado na controvérsia sobre a custodia entre Franco Pastori ${ }^{132}$ e Siro Sollazzi, ${ }^{133}$ que se detiveram com maior atenção na análise de Gai. 3, 196, 202-206, seria o estritamente "histórico-dogmático"

O pressuposto da teoria "dogmática-materialista" é que qualquer axioma deriva de uma luta perpétua dos contrários, que ocorre tanto no campo teórico, como também no pragmático. E qualquer axioma jurídico também somente poderia ser alcançado após " $i$ dolori del parto" [= "as dores do parto"].134

uma responsabilidade objetiva, pois existem contratos em que a responsabilidade do devedor é objetiva, e somente esse juízo teria operado.

129 POLÁCEK, Vojtech. op. cit., p. 161-184.

130 POLÁCEK, Vojtech. op. cit., p. 161.

131 POLÁCEK, Vojtech. op. cit., p. 161. Para ele, o melhor caminho que se apresenta muitas vezes é deixar de lado a possibilidade de incompatibilidade entre as instituições e institutos antigos pelo fato de que em cinco milênios de documentos escritos o homem em si não mudou muito, principalmente em sua qualidade pessoal e nos fenômenos sociais, que "erano " allora » gli stessi o quasi di " oggi »". Além disso, acompanhando o desenvolvimento do método "dogmático" de análise do Direito Romano, a sociedade humana desenvolveuse não de forma retilínea ou circular, mas sim espiral, isto é, a sociedade humana atravessa formas que aparentemente já passou, mas sempre em uma base mais alta. Trata-se de um processo progressivo e ascendente, onde de um estado qualitativo velho se passa para um novo estado qualitativo.

132 PASTORI, Franco. Gaio ... cit., p. 291-326, e PASTORI, Franco. Il commodato ... cit., p. XV-476.

133 SOLAZZI, Siro. La responsabilità ... cit., p. 139-145, Una fovola cit. (nota 111), pp. 89-92, e SOLAZZI, Siro. Recensão ... cit., p. 258-270.

134 Cf. POLÁCEK, Vojtech. op. cit., p. 162. Toda a contribuição de Vojtech Polácek para a problemática da 
O tema da custodia teria que ser mais uma vez enfrentado, mas se mudando o critério histórico para outro diverso: o da "dialética" dos critérios de responsabilidade. ${ }^{135}$

3.3. A terceira geração exegética de escritores sobre o comodato: a "sobre-vida" da segunda geração e a ressurreição da controvérsia sobre a expressão "custodiam praestare"

A tese de Franco Pastori e os ataques a essa realizados acabaram, por um lado, em determinar uma doutrina que apoia incondicionalmente a tese dominante, representada por Vincenzo Arangio-Ruiz, Giuseppe Ignazio Luzzatto e Franco Pastori, ${ }^{136}$ segundo a qual, no período clássico, o comodatário responderia por custodia, e, no justinianeu, por culpa; e, por outro, pesquisadores que possibilitaram a abertura de novas perspectivas para a responsabilidade do comodatário. ${ }^{137}$

Assim, embora grande parte da terceira geração de escritores apenas confirme a tese dominante da segunda geração ${ }^{138}$, também surgiram posicionamentos doutrinários nos mais diversos sentidos, cujo denominador comum é a percepção de que se a segunda geração representou um grande avanço ao aplicar uma evolução histórica à responsabilidade do comodatário, também falhou ao atribuir demasiada rigidez a divisão dos períodos do Direito Romano, não permitindo assim o diálogo entre os critérios de responsabilidade do comodatário. ${ }^{139}$

Assim, nesta tendência de "copiar", sem, ou com poucos, avanços, para Antonino Metro, ${ }^{140}$ da mesma forma que se fala de "praestare dolum" e "praestare culpam" na época justinianéia, ao se afirmar que o comodatário "custodiam et dolum praestat", somente se pode estar fazendo uma alusão ao período clássico romano.

custodia parte do ponto de vista do "materialismo histórico", o que não significa invocar questões políticas ou sociais dentro de um critério de responsabilidade específico.

135 Cf. POLÁCEK, Vojtech. op. cit., p. 162-163.

136 Cf., entre outros, METRO, Antonino. «Custodiam praestare ». Labeo (Rassegna di Diritto Romano), v. 13, 1967, p. 60-67; MERCADO, Javier Belda. op. cit., p. 1-23.; e, parcialmente, TARDIVO, Carlo-Maria. op. cit., p. 82-91.

137 Cf., principalmente, SCHERILLO, Gaetano. op. cit., p. 981-992; SERTORIO, Luigi. op. cit., p. 41-43; e POLÁCEK, Vojtech. op. cit., p. 161-184; e, a surpresa, apesar da data do escrito, HAYMANN, Franz. Textkritische Studien zum römischen Obligationenrecht - I - Über Haftung für Custodia. SZ (Zeitschrift der Savigny-Stiftung für Rechtsgeschichte - Romanistische Abteilung), v. 40, 1919, p. 167-350 (= §1-7).

138 Esta primeira vertente de escritores da terceira geração, embora se proclamem trazer teses originais, apenas podem ser inseridos em uma nova geração didaticamente, pois substancialmente não fizeram nada mais do que manter vigorando o posicionamento da segunda geração até os dias atuais. Trata-se de uma zona cinzenta em que a tese da segunda geração confunde-se com a defesa da terceira.

139 Cf. POLÁCEK, Vojtech. op. cit., p. 161-184

140 METRO, Antonino. op. cit., p. 60. 
Antonino Metro ${ }^{141}$ expressamente afirma fazer parte da tese dominante defendida por Vincenzo Arangio-Ruiz, Giuseppe Ignazio Luzzatto e Franco Pastori.

Javier Belda Mercado, ${ }^{142}$ sustentando a tese tradicional, vislumbra que a exactissima diligentia custodiendae rei $i^{143}$ somente pode ser de natureza subjetiva, uma vez que se insere dentro da estrutura de Justiniano e a custodia técnica somente seria conhecia no período clássico.

O mesmo resultado seria alcançado em outras passagens dos Digesta, como em Ulp. 28 ad ed., D. 13, 6, 5, 3-4. Segundo Javier Belda Mercado, ${ }^{144}$ a responsabilidade do comodatário seria em ambos os textos reorganizada para se adequar à regra da utilitas contrahentium.

$\mathrm{Na}$ segunda vertente, a terceira geração criou uma série de tendências quanto à responsabilidade do comodatário. Destacam-se as teses de Gaetano Scherillo, ${ }^{145}$ Luigi Sertorio ${ }^{146}$ e de Franz Haymann. ${ }^{147}$

Com uma posição nitidamente minoritária, Gaetano Scherillo ${ }^{148}$ defende, em seu verbete, que o critério da culpa já existia desde o período clássico, justamente por estar presente, em um texto de Pomp. 21 ad. Quint. Muc. D. 13, 6, 23, o princípio da utilitas contrahentium --que teria sido também utilizado em Gai. 3, 206-207, para fundamentar o "custodiam praestare" - e o diagnóstico da duplicidade formular já nessa época.

Por outro lado, também seria um equívoco acreditar que somente o critério da culpa existiria no período justinianeu por meio da exacta diligentia custodiendae rei - Inst. 3, 14, 2; Gai. 2 aureor., D. 44, 7, 1, 4; e Gai. 9 ad ed. provinc., D. 13, 6, 18 pr. -, uma vez que seu nome seria uma mescla (culpa e custodia), o que apenas caracterizaria o fenômeno da custodia. ${ }^{149}$

$\overline{141}$ METRO, Antonino. op. cit., p. 61. Para ele, as fontes romanas sobre a custodia do comodatário devem ser consideradas inatacáveis e a expressão "custodiam praestare" não pode ser entendida como prestação contratualmente devida, que teria uma estrutura análoga, embora de certo modo oposta, na expressão "dolum praestare", uma vez que isso levaria a sustentar que o devedor seria obrigado a assegurar um determinado resultado, sendo que, por esta, ele deveria se abster de um comportamento, enquanto que, por aquela, ele deveria apresentar certo comportamento. Ao se alargar a perspectiva e o horizonte da pesquisa, a única certeza que se pode ter é que o verbo "praestare" aparece claramente, no latim jurídico "anfibiológico", talvez como em pouquíssimos outros casos, sendo aplicado, no âmbito da responsabilidade contratual, no mesmo sentido, que não pode ser outro se não aquele de "rispondere, esser tenuto"

142 MERCADO, Javier Belda. op. cit., p. 5.

143 Gai. 2 aureor., D. 44, 7, 1, 4. No mesmo sentido HAYMANN, Franz. op. cit., p. 202-204

144 MERCADO, Javier Belda. op. cit., p. 8-10, 15-16.

145 SCHERILLO, Gaetano. op. cit., p. 981-992.

146 SERTORIO, Luigi. op. cit., p. 41-43.

147 HAYMANN, Franz. op. cit., p. 167-350 (= § 1-7).

148 SCHERILLO, Gaetano. op. cit., p. 990.

149 SCHERILLO, Gaetano. op. cit., p. 989-990. O comodatário responderia, segundo Gaetano. Scherillo, por uma responsabilidade multifacetada - por dolus, culpa e custodia - desde o período clássico até o justinianeu. 
Luigi Sertorio ${ }^{150}$ sustenta que tanto no período justinianeu, em Ulp. 28 ad ed., D. 13, 6, 5, 4, como no Direito moderno e contemporâneo, em sua época o art. 1.810 do CC Italiano de 1865 , atual art. $1.805, \S 1^{\circ}$ do CC Italiano, o "princípio do sacrifício da coisa própria" seria uma hipótese de responsabilidade objetiva do comodatário.

Para terminar, a tese de Franz Haymann ${ }^{151}$ baseia-se em Ulp. 28 ad ed., D. $13,6,5,3$.

O comodatário responderia objetivamente - "omne periculum" - quando a coisa emprestada tivesse sido avaliada. A grande novidade da tese de Franz Haymann, mesmo sustentada a origem clássica do texto, é afirmar que a expressão "omne periculum" foi mantida, em época justinianéia, com um intuito particular, ou seja, imputar ao comodatário a responsabilidade por custodia. ${ }^{152}$

Mais importante ainda na defesa de Franz Haymann ${ }^{153}$ é que este texto seria a prova definitiva da coexistência dos critérios da culpa e da custodia no período justinianeu. Isso implica na configuração de uma responsabilidade multifacetada do comodatário, que, sem a avaliação, responderia subjetivamente, mas, com a avaliação, objetivamente, e demonstra, que talvez os jurisconsultos da época do Imperador Justiniano não desejassem excluir totalmente a responsabilidade objetiva, ou por custodia.

4. Conclusão

Depois da análise dos dois assuntos propostos, passa-se a descrição de algumas breves conclusões.

Parece também que CARDILLI, Riccardo. L'obbligazione di " praestare » e la responsabilità contrattuale in diritto romano (II sec. a.c. II sec. d.c.). Milano: Giuffrè, 1995, p. 496-503, interpretando Gai. 9 ad ed., D. 13, 6, 18 pr., acredita em uma igualdade de sentidos entre a expressão "custodiam praestare" e a responsabilidade do diligentissimus paterfamilias, embora a compilação justinianéia funde-se na culpa.

SERTORIO, Luigi. op. cit., p. 41-43. Embora TARDIVO, Carlo-Maria. op. cit., p. 82-91, siga, em regra, o posicionamento da segunda geração, quanto ao texto de Ulp. 28 ad ed., D. 13, 6, 5, 4, onde vem escrito o "princípio do sacrifício da coisa própria", ele acredita que se trate de um típico caso de responsabilidade por custodia até mesmo no período justinianeu, devido à particularidade da fattispecie e à subentendida distinção entre casus minor e vis maior. Realiza um raciocínio muito semelhante ao realizado por CARRESI, Franco. Il comodato - Il mutuo. In: VASSALI, Filippo (Org.). Trattato di Diritto Civile Italiano. Torino: UTET, 1950 , v. 8 , t. 2, p. $59-61$, quanto aos arts. $1.804, \S 1^{\circ}$, e $1.805, \S 1^{\circ}$ do CC Italiano, ao sustentar que o critério geral de responsabilidade do comodatário é a culpa levis in abstracto, mas na hipótese do "princípio do sacrifício da coisa própria" - art. $1.805, \S 1^{\circ}$ do CC Italiano - a responsabilidade seria objetiva.

151 HAYMANN, Franz. op. cit., p. 167-169, 188-189. Embora o texto seja um artigo científico publicado na Zeitschrift der Savigny-Stiftung für Rechtsgeschichte - Romanistische Abteilung, de 1919, o posicionamento de seu autor é tão singular que seria absolutamente inadequado inseri-lo na primeira ou segunda geração de escritores.

152 A tese de Franz Haymann foge do foco de críticas que se faz à expressão "praestandam culpam et diligentiam", considerada como uma interpolação. Ele busca as demais expressões contidas no texto. Esse é o caminho encontrado para ligar a responsabilidade por custodia à res aestimata. 
Quanto à nomenclatura do instituto, fica claro que tanto "utendum dare", que se refere ao objeto do negócio jurídico, quanto "commodare", o qual se relaciona ao vínculo jurídico gratuito, impõe o beneficium tribuere (implicam, por si, "a entrega da coisa", um dinamismo). Desta forma, o nome do instituto "comodato" - reflete o caráter real do contrato e um agir daquele que é seu credor. E, assim, a formalidade das causae obligationis do Direito Romano enraizou-se, ao menos, em sua terminologia.

Quanto à responsabilidade do comodatário, é, de fato, difícil compreender o que se deseja alcançar igualando, no período justinianeu, a conduta do comodatário com a do diligentissimus paterfamilias, podendo-se até mesmo pensar em uma figura utópica e ideal, dotada de uma visão profética capaz de evitar acasos que as pessoas, em regra, não conseguem. ${ }^{154}$

Mas, justamente, trata-se de um personagem que, por seu nome, refere-se a um critério subjetivo de responsabilidade, mas não se encontra distante da custodia técnica romana. ${ }^{155}$

Deve-se ainda lembrar do "fenômeno de enfraquecimento" do comodato descrito por Max Kaser, ${ }^{156}$ que, realmente, atingiria a figura da custodia, ganhando a culpa campo de aplicação até mesmo antes do período pós-clássico.

Um acontecimento que não destruiu nem o contrato de comodato, nem o critério da custodia técnica, já desencadeando o que a terceira geração atualmente entende pelo diálogo dos critérios de responsabilidade.

Portanto, a partir do estudo de sua nomenclatura e da responsabilidade de seu devedor, conclui-se não ser possível atualmente compreender o comodato sem trabalhar com duas expressões centrais "beneficium tribuere" e "custodiam praestare" - e se pode ter certeza que alguns aspectos do comodato ainda continuam em aberto e representam um campo de pesquisa infindável para a responsabilidade civil.

São Paulo, março de 2010.

154 ZIMMERMANN, Reinhard. op. cit., p. 192.

155 ZIMMERMANN, Reinhard. op. cit., p. 192-193. O autor explica que a esse nome decorre da tendência justinianéia, reforçada pelo cristianismo, de fundamentar o sistema de responsabilidade na culpa. Assim, tentou-se gerar critérios subjetivos sobre os tradicionais clássicos. Entretanto, o comodatário não deixou de responder por alguns acasos, o que não destoa em nada da custodia técnica. Seria o que ocorre, principalmente, em Gai. 9 ad ed. provinc., D. 13, 6, 18 pr., e Gai. 2 aureor, D. 44, 7, 1, 4. No mesmo sentido, BERGER, Adolf. op. cit., p. 423.

Cf., também, sobre a falta de necessidade desses critérios e a responsabilidade do comodatário, VAZ SAMPAIO, Rodrigo Lima. Da Responsabilidade ... cit., p. 1027-1074; e SAMPAIO, Rodrigo Lima Vaz. Da Responsabilidade Objetiva ... cit., p. 771-840.

156 KASER, Max. Das römische Privatrecht - Die nachclassischen Entwicklungen. München: Beck, 1959. v. 2, p. $271(=\S 262)$. Quatro institutos teriam enfraquecido o comodato: mútuo, locação/ arrendamento, precarium, e depósito. 


\section{Referências}

ARANGIO-RUIZ, Vincenzo. Istituzioni di diritto romano. 14. ed. Napoli: Jovene, 2006.

Arangio-Ruiz, Vincenzo. Responsabilità contrattuale in diritto romano. 2. ed. Napoli: Jovene, 1987. BARON, Julius. Die Haftung bis zur höheren Gewalt. Archiv für die Civilistische Praxis, v. 78, p. 202-310, 1892.

BARON, Julius. Diligentia exactissima, diligentissimus paterfamilias oder die Haftung für Custodia. Archiv für die Civilistische Praxis, v. 52, p. 44-95, 1869.

BARON, Julius. Pandekten. 9. ed. Leipzig: Duncker \& Humblot, 1896.

BERGER, Adolf. Encyclopedic Dictionary of Roman Law. Philadelphia: American Philosophical, 1980 .

CARDILLI, Riccardo. L'obbligazione di "praestare" e la responsabilità contrattuale in diritto romano (II sec. a.c. - II sec. d.C.). Milano: Giuffrè, 1995.

CARRESI, Franco. Il comodato: Il mutuo. In: VASSALI, Filippo (Org.). Trattato di diritto civile italiano. Torino: UTET, 1950. v. 8, t. 2, p. 5-136.

FERRARIO, G. A. Comodato. In: ENCICLOPEDIA GIURIDICA ITALIANA, 1930, v. 3, p. 385405.

FERRINI, Contardo. Storia e teoria del contratto di commodato nel diritto romano. In: OPERE di Contardo Ferrini - Studi vari di diritto romano e moderno - Sulle obbligazioni, sul negozio giuridico, sulle presunzioni. Milano: Ulrico Hoepli, 1929, v. 3, p. 81-203

FORCHIELLI, Paolo. I contratti reali. Milano: Giuffrè, 1952.

GIRARD, Paul Frédéric. Manual élémentaire de droit romain. 4. ed. Paris: Arthur Rousseau, 1906. HASSE, Joham Christian. Die « Culpa » des römischen Rechts. 2. ed. Bonn: Adolph Marcus, 1838. HAYMANN, Franz. Textkritische Studien zum römischen Obligationenrecht - I - Über Haftung für Custodia. Zeitschrift der Savigny-Stiftung für Rechtsgeschichte - Romanistische Abteilung, v. 40, p. $167-350,1919$.

HEUMANN, Hermann Gottlieb; SECKEL, Emil. Handlexicon zu den Quellen des römischen Rechts. 9. ed. Jena: Gustav Fischer, 1926.

KASER, Max. Das römische Privatrecht: Die nachclassischen Entwicklungen. München: Beck, 1959. v. 2 .

Krückmann, Paul. Custodia. Zeitschrift der Savigny-Stiftung für Rechtsgeschichte - Romanistische Abteilung, v. 64, p. 1-56, 1944.

KUNKEL, Wolfgang. "Diligentia ». Zeitschrift der Savigny-Stiftung für Rechtsgeschichte Romanistische Abteilung, v. 45, p. 266-351, 1925. 
LENEL, Otto. Das Edictum Perpetuum: Ein Versucht zu seiner Wiederherstellung. 3. ed. Leipzig: Tauchnitz, 1927.

LUZZATTO, Giuseppe Ignazio. « Commodati... vel contra ». Labeo: rassegna di diritto romano, v. 2, p. 357-362, 1956.

LUZZATTO, Giuseppe Ignazio. Caso fortuito e forza maggiore come limite alla responsabilità contrattuale: la responsabilità per custodia. Milano: Giuffrè, 1938. v. 1 .

MARMITT, Arnaldo. Comodato. 3. ed. Rio de Janeiro: AIDE, 2002.

MAYR, Robert. « Praestare ». Zeitschrift der Savigny-Stiftung für Rechtsgeschichte - Romanistische Abteilung), v. 42, p. 198-227, 1921.

MERCADO, Javier Belda. La responsabilidad del comodatario en el derecho romano. Revista Electrónica de la Facultad de Derecho de la Universidad de Granada, Granada, p. 1-23, 2007.

METRO, Antonino. «Custodiam praestare ». Labeo: Rassegna di Diritto Romano), v. 13, p. 60-67, 1967.

MICHEL, Jacques. Gratuité en droit romain. Bruxelles: Université Libre de Bruxelles - Institut de Sociologie, 1962.

ALVES, José Carlos Moreira. Direito romano: instituições de direito romano... 6. ed. Rio de Janeiro: Forense, 2005. v. 2.

PASTORI, Franco. Gaio e la responsabilità contrattuale. Labeo: Rassegna di Diritto Romano, v. 2, p. $291-326,1956$.

PASTORI, Franco. Il commodato in diritto romano. 3. ed. Milano: Cisalpino, 1995.

PASTORI, Franco. Sulla duplicità formulare dell' « actio commodati ». Labeo: Rassegna di Diritto Romano, v. 2, p. 89-94, 1956.

PFLÜGER, Heinrich Hackfeld. Zur Lehre von der Haftung des Schuldners nach römischen Recht. Zeitschrift der Savigny-Stiftung für Rechtsgeschichte - Romanistische Abteilung, v. 65, p. 121-218, 1947.

POLÁCEK, Vojtech. Comodato e furto: spunti d'interpretazione dialettica. Labeo: Rassegna di Diritto Romano, v. 19, p. 161-184, 1973.

MIRANDA, Francisco Cavalcanti Pontes de. Tratado de direito privado: parte especial... 2. ed. Rio de Janeiro: Borsoi, 1964. t. 46.

POTHIER, Robert-Joseph. Traités du prêt a usage et du precaire. In: CEuvre de Pothier (1844). 3. ed. Paris: Marchal et Billard, 1890, t. 5, p. 1-38 (=ns. 1-97).

SCHERILLO, Gaetano. Comodato (diritto romano). In: ENCICLOPEDIA DEL DIRITTO, v. 7, 1960 , p. $981-992$. 
SERTORIO, Luigi. La "culpa in concreto" nel diritto romano e nel diritto odierno. Torino: Fratelli Bocca, 1914.

SOLAZZI, Siro. La responsabilità del commodatario nelle Istituzioni di Gaio. IURA: Rivista Internazionale di Diritto Romano e Antico, v. 6, p. 139-145, 1955.

SOLAZZI, Siro. Recensão a PASTORI, Franco. Il commodato nel diritto romano - Con contributi allo studio della responsabilità contrattuale. Milano: Giuffrè, 1954.

SOLAZZI, Siro. Recensão a PASTORI, Franco. Il commodato nel diritto romano - Con contributi allo studio della responsabilità contrattuale. IURA: Rivista Internazionale di Diritto Romano e Antico, v. 6, p. 258-270, 1955.

SOLAZZI, Siro. Una favola su Gai 3.204. Labeo: Rassegna di Diritto Romano, v. 3, p. 89-92, 1957.

TARDIVO, Carlo-Maria. Studi sul « commodatum ». Archivio Giuridico "Filippo Serafini". v. 204, p. 5-91, 1983.

TROPLONG, Raymond-Théodore. Le droit civil expliqué: Du prêt. Paris: Charles Hingraus, 1845. t. 14 .

VAZ SAMPAIO, Rodrigo Lima. Da responsabilidade do comodatário pelo caso fortuito ou de força maior acerca do princípio do sacrifício da coisa própria. Revista da Faculdade de Direito da Universidade de São Paulo, São Paulo, v. 103, p. 1.027-1.074, jan./dez. 2008.

VAZ SAMPAIO, Rodrigo Lima. Da responsabilidade objetiva do comodatário no direito romano. Revista da Faculdade de Direito da Universidade de São Paulo, São Paulo, 104, p. 771-840, jan./ dez. 2009.

WEISS, Egon. Institutionen des römischen Privatrechts. 2. ed. Basel: Recht und Gesellschaft, 1949. ZANNINNI, Pierluigi. Comodato nel diritto romano. Digesto delle Discipline Privatistiche, v. 3, p. 31-34, 1998.

ZIMMERMANN, Reinhard. The law of obligations: Roman Foundations of the Civilian Tradition. London: Oxford, 1996. 